\title{
Ethical Thoughts in Accounting And Their Effects On Accounting Practice
}

\author{
William Smart Inyang ${ }^{1 *}$ John Ogenyi Oboh ${ }^{2}$ Rex Tobechukwu Nwabuikem ${ }^{3}$ \\ 1. Department of Accounting, University of Calabar, P.M.B. 1115, Calabar, Cross River State, Nigeria. \\ 2. Department of Accounting, University of Calabar, P.M.B. 1115, Calabar, Cross River State, Nigeria. \\ 3. Department of Accounting, University of Calabar, P.M.B. 1115, Calabar, Cross River State, Nigeria. \\ * E-mail of the corresponding author: wismarti@gmail.com
}

\begin{abstract}
This study examined the effect of ethical thoughts in accounting on accounting practice in Nigeria. To achieve this objective, data were collected from primary sources through a well-structured questionnaire of four sections of twenty questions administered to a sample of one hundred and sixty one (161) out of which one hundred and forty eight (148) were completed and returned. The questionnaires were administered to the registered members of the ICAN District Society in Calabar, Nigeria and data generated from the questionnaires were analysed using IBM SPSS V.20. The results revealed a significantly negative relationship between ethical thoughts and the accounting practices of corporate organizations in Nigeria. On the basis of the findings, the study recommended the following among others: Professional accountants as custodians and producers of accounting information should adhere to the codes of professional best practices issued by relevant professional bodies. Each organization in Nigeria should establish ethics departments to ensure that activities are in line with the codes of ethics, including the financial reporting process. The composition of the Board of Directors and Audit Committees should be made up of people with corporate experience, proven integrity and financial expertise. Greater efforts should be made by the relevant professional bodies to review their various ethical codes guiding members' conduct or behaviour in practice and widespread enlightenment coupled with stiffer penalties for professional misconduct could also be a way out.
\end{abstract}

Keywords: Integrity, objectivity, professional behaviour, professional competence and due care and accounting practice.

DOI: $10.7176 /$ RJFA/10-6-16

Publication date:March $31^{\text {st }} 2019$

\section{Background of the study}

Recently, the plethora moral bloopers and corporate financial scandals have brought to light the imperative nature of the topic. This has led to corporate organisations adopting ethical codes and applying measures to strengthen ethical, legal and social safeguards. Although the issue of corporate scandals is not new, the increase in its occurrence during the early 2000 s was rather alarming.

Ethics in the accounting profession was for long associated only with accounting scholars, investors and accounting bodies around the world. The general notion to this is the public perception that organizations should strive towards ethical transparency. The concept of ethics simply deals with how decisions affect other people and organizations. Yet, one of the unique features of most recognized trades and vocations including the highly regulated accounting profession is the existence of code of ethics which are the criteria of global best practices. The society evaluates the performance of professionals on the basis of both moral and technical codes. Adherence to these codes by the practitioners of the profession improves confidence in the work of the professional by shareholders who depends on the auditor's opinion as a means of evaluating the integrity of financial statements.

The recurrent corporate failures and financial statement fraud in recent times has staggered public trust in the profession from various stakeholders, leading to increased demand for ethics within the profession.

Inevitably the inherent risks in the business environment, the potential for business failure, or the possibility of human error cannot be totally eliminated, the principle of professional ethics requires professional accountant to conduct themselves honestly, and in accordance with applicable professional standards.

Traditionally, the key feature of a profession is anchored on the grant of a special franchise by society who expects the practitioners of that profession to accept responsibility to provide a degree of regulation and enforcement through expert advice and persuasion thus, relieving the society of the burden of providing that control by other means (Mautz, 1988). A profession is distinguished by the general belief in its ability to deliver 
unique, specialized and restricted services to the public and the development of an internal rules aim at guiding, directing and regulating members' professional conduct.

The current business environment has put professional services firms at crossroads. The values of individuals, and the integrity of the organizations they belong to, are being tested.

Generally, accounting ethical practices revolves round the principles of objectivity, integrity, confidentiality, professional behaviour, competence and due care. Failure on the part of the practicing accountants or auditors to exhibit due care and diligence in carrying out their responsibilities and lack of integrity impinges on the credibility of the accountancy profession. It has been argued that the role they play in similar exercises is unethical, for example, accountants give advice on mergers but fails to consider the implication of the exercise on employees.

In spite of the important roles played by ethical thoughts in the accounting profession, these researchers have not come across any study that has specifically disclosed how the application of integrity, objectivity, professional behaviour and professional competence/due care affect the accounting practices of corporate organizations in Nigeria. The purpose of this research is to establish the kind of relationship that exists between the foregoing ethical principles and accounting practices in Nigeria. How are the accounting practices of corporate organisations in Nigeria influenced by ethics of integrity, ethics of objectivity, ethics of professional behaviour and ethics of professional competence/due care? This research is therefore, anchored on the argument that the application of ethics of integrity, ethics of objectivity, ethics of professional behaviour and ethics of professional competence/due care has not significantly improved the accounting practices of corporate organizations in Nigeria.

\section{Statement of the research problem}

Ethics is about morality, and acting in a way that is morally justified. This singular factor has its footprint in every field including the accounting profession. Ethical thoughts with regards to the accounting profession refer to qualities such as Integrity, Confidentiality, Professional Competence and Due Care, Objectivity and Professional Behaviour. These values or principles are of general acceptance within the profession and therefore, accountants have a duty to act in the public interest and due to the probable conflict of interest between management and shareholders (owners of the company); accountants in practice are expected to be one of the most ethical practitioners as they both on one hand prepare and on the other give assurance to these accounts.

Quite unfortunately, negligence in the accounting profession comes with its costs therefore individuals and firms alike bear the consequences when faulted. This refers to the likes of Lever Brothers PLC and Cadbury Nigeria who overstated their earnings through window dressing of accounts. Moreover the recent Skye bank now Polaris bank the then previously acquired Mainstreet bank limited case is an indicator that despite the rush to adopt measures that restrict openings which could lead to corporate scandals or failures, these things still occur involving the input of accountants.

Skye bank resulted as a merger of five banks and in no time emerged as one of the eight systematically important banks (SIB) captioned as too big to fail. Its downfall started with Mainstreet bank's acquisition where an asset valued at a book value of $\$ 1$.2billion and recognised at $\$ 5$.5billion in arriving at the purchase consideration was found to be actually under a lease arrangement of which Mainstreet bank had recorded it as a freehold building. They ended up paying rentals for what they previously thought they had title to. Also, Mainstreet banks' acquisition was through a process which the law under CAMA section 159 (2b) frowns at. In which the law clearly prohibits a firm from aiding its intending parent in funding the acquisition. Skye bank played a fast game by acquiring Mainstreet bank on October $30^{\text {th }}$, just a few days ahead of the transaction closing date of November $3^{\text {rd }}$, through funds borrowed from four banks amounting to $\$ 100$ billion which was the remaining of the $\$ 126$ billion purchase consideration ahead of the soon arriving redemption date of MBL AMCON bonds with which it then used in paying back the loans (The rise, the fall and the bridge, 2018).

The study therefore attempts to reveal the behavioural quality of accountants and their management collaborators who have both authored and endorsed the accounts contained in the financial statements presented by the organization. Of which such financial statements cannot be reliable if the behavioural accountability of those behind them are questionable. Therefore, the study is set to examine how ethical thoughts influence accounting practice in Nigeria. How have these ethical thoughts influenced the accounting practices of corporate organizations in Nigeria?

\section{Objectives of the study}

The broad objective of the study is to examine the effect of ethical thoughts in accounting on accounting practices in Nigeria. The specific objectives are to:

1. Examine the extent at which ethics of integrity influences accounting practice. 
2. Examine the extent at which ethics of objectivity influences accounting practice.

3. Examine the extent at which ethics of professional behaviour influences accounting practice.

4. Examine the extent at which ethics of professional competence and due care influences accounting practice.

5. To make recommendations based on the findings of this research.

\section{Research questions}

The research questions for the study are as follows:

1. To what extent does the ethic of integrity influence accounting practice?

2. To what extent does the ethic of objectivity influence accounting practice?

3. To what extent does the ethic of professional behaviour influence accounting practice?

4. To what extent does the ethics of professional competence and due care influence accounting practice?

\section{Research hypotheses}

The following hypotheses were formulated for the study;

$\mathrm{H}_{1}$ : There is no significant relationship between ethics of integrity and accounting practice.

$\mathrm{HO}_{2}$ : There is no significant relationship between ethics of objectivity and accounting practice.

$\mathrm{HO}_{3}$ : There is no significant relationship between ethics of professional behaviour and accounting practice.

$\mathrm{HO}_{4}$ : There is no significant relationship between ethics of professional competence and due care and accounting practice.

\section{Scope of the research area}

This research study revolves round the effect of good ethical values on accounting practices as far as accounting firms and services industries are concerned in Nigeria. The activities of the accounting professional bodies were put also into consideration. However, the research was limited to accounting professionals, audit and accounting firms operating in Cross River State.

\section{Significance of the study}

Ethics are of immense importance to the accounting profession. Ethics are the principles and values used by an individual to govern his or her actions and decisions. The significance of this study is multi-faceted. At first it will help in identifying the essence of ethical principles on the accounting practice which will increase the public trust and credibility accorded to audited financial statements without much scepticism about the objectivity of the auditor in performing his duties. The study also is important to developing countries such as Nigeria with high rates of corruption and recurrent corporate malpractices as it will help narrow down the options to curtail such from subsequent occurrence.

This study will also be significant to financial analysts, investors, public accountants and the general public as the integrity of the prepared statements will give no rise for fraud or material misstatements that are liable to give a false impression or appearance to the stakeholders. It goes as far as preventing unethical practices such as earnings management and windowed dressing of accounts.

It will therefore equally be of immense help to organizations in the financial reporting aspect gendering on professional competence and due care where the expertise of the professional is expected to play out in handling complex situations and ensuring that all his decisions and actions are sustained within the ethical boundaries governing the profession. Finally this research will be significant to persons within the academic environment and also independent researchers as it will serve as a reference point also for future studies on this subject. 


\section{Operational definition of terms}

\subsection{Ethical Thoughts: Ethical thoughts are Integrity, Objectivity, Professional behaviour and Professional} competence and due care

8.2 Integrity: This can be defined as the number of unqualified reports issued on financial statements in relation to the qualified reports.

8.3 Objectivity: This can be defined as the existence and compliance to the dictates of internal ethics council or units within an organisation.

8.4 Professional Behaviour: This can be defined as the extent of consciousness, awareness and adherence to statutory regulations governing the accounting profession for example CAMA 2018 (as amended), IFRS and ISA including their disclosure requirements.

8.5 Professional Competence and due care: This is the frequency at which an auditor accurately and precisely detects errors in a financial statement.

8.6 Ethical Accounting: Ethical accounting is the frequency at which financial statements are found to be true and fair, devoid of error and generated wholly in view of public interest.

8.7 Accounting Practice: Accounting practice is defined in this study as the absence or non-occurrence of corporate frauds or scandals.

8.8 Accounting Practitioner: A person who has the requisite skill and experience in establishing and maintaining accurate financial records for an individual or business having passed certain examinations and met all other statutory and licencing requirements.

\section{Theoretical Framework}

There are many theoretical frameworks for this study but, we intend to restrict ourselves to the agency theory and the theory of imperative principle. This is because most of the empirical studies that will be reviewed in this work have disclosed the pursuance of self-interest and the positive effect of due process which are all present in agency theory and imperative principle respectively.

9.1 Agency theory: Agency theory was developed by Jensen and Meckling (1976) who defined the agency relationship as a form of contract between a company's owners and its managers, where the owners appoint an agent (the managers) to manage the company on their behalf. As a part of this arrangement, the owners must delegate decision-making authority to the management. The owners expect the agents to act in the best interests of the owners. Ideally, the 'contract' between the owners and the managers should ensure that the managers always act in the best interests of the shareholders. There is an agency relationship when actions of one individual affect both his welfare and that of another person; it can be an implicit or explicit contracted relationship. In an agency relationship, if both parties' interests are actualized, there is a good reason to believe that the agent acts in the interest of the principal. In this study, the professional accountant and management of the organization including the various stakeholders are the agents while the shareholders constitute the principal. This dual ethical structure of the accountant having to report to the management as an employee and also fulfil his professional duties in bearing the public interest at heart based on the nature of his qualification and the regulations surrounding it, however makes it impossible to arrange a perfect contract and agency conflict will 
surface because management may have desires which regulations guiding the accounting profession in Nigeria may prohibit the agent from indulging in such.

\subsection{The imperative principle}

This principle suggests a decision maker acts according to the requirements of an ethical rule. Some forms of imperative ethics maintain that a decision should be made without trying to predict whether an action will probably create the greatest balance of good over evil. Ethics in the imperative sense are a function of moral rules and principles and do not factor in a circumstance-specific calculation of consequences. The philosopher Immanuel Kant (1724-1804) was one the foremost supporter of the imperative school. Kant was unwilling to rely only on decision makers' natural dispositions and values for decisions in various circumstances. He strongly preferred rules without exceptions to the varied and frequently inconsistent choice of individuals (Robertson and Louwers, 2002). He maintained that reason and the strict duty to be consistent governed the formulation of his first law of conduct. One of Kant's rules is 'live up to all your professional duties not to knowingly misrepresent facts'. Another is the duty to 'Be loyal to your employer'. However, conflicts of rules and duties may create difficult problems because adherence to one means breaking the other

Most professional codes of ethics have features of the imperative type of theory. However, society frequently questions not only conduct itself but the rules on which conduct is based. Therefore, an opinionated imperative approach to ethical decisions may not be entirely adequate for the maintenance of professional standards. Society may question the rules, and conflicts among them are always possible. The increasing gap in audit expectation gap is point for consideration. Since the Kantian imperative theory does not provide an easy way to decision making, someone who is rule bound may find himself or herself in a dilemma.

\section{Empirical Review of Literature}

Many empirical studies have also found support for the agency theory which discloses that individuals pursue their self-interests when they are entrusted with resources and responsibilities. The society's propensity for materialism is the root cause of unethical conducts in public sector and financial institutions in Nigeria. Most professional accountants believe that the position of an accountant is the position of wealth. In order to achieve their selfish interest, they abuse their professional code of ethics, particularly when they have the opportunity to exercise professional judgment (Frenchman 1998 and Nwagboso 2008). It is therefore, no news to say that the entire globe is witnessing serious erosion in ethical values. Even more honest persons as Pastors, Imams, and other religious people, may find it difficult to act in an ethical manner in some situations. Professional accountants face some challenges that make them behave unethically. Anyone familiar with the perennial distress in the Nigerian banking industry knows that one main cause is the questionable and often illegal wheeling and dealing not to mention outright fraud of many professional accountants who shamelessly compromised the once "sacred" ethics to their profession. What can be said of banks, which were issued a clean bill of health by professional accountants only to sink into distress and bankruptcy within a twinkle of an eye? Was it possible that there were no signs of failure visible to the accountant? What about the case revealed by Prof. Charles Soludo the former Governor of the Central Bank of Nigeria, that the financial statements of most banks were misrepresentation of facts? Could it be that the accountants do not know the right thing to do? Far from it. Yet another problem is the accountant's involvement or the ever-increasing propensity to turn up on the all sides of client's activities. Some professional accountants not only audit their client's books, but also help in preparing such accounts and have also turned up in different advisory capabilities. These will not only jeopardize the secured independence quality, but will also aggravate the already existing crises of confidence in the one revered noble profession of accounting (Nigam, 2008).

The objective of any business is the maximization of profit in order to increase the company's share price. But increased competition in the business world has eroded the company's objective. The pressure to succeed therefore and remain at the top is responsible for the changes in contemporary business practices whereby standards of behaviour expected from professionals are being abused (Aquaok \& Life, 2010). This has caused chief executive of companies to put pressure on professional accountants to manipulate accounting data through rule bending and loophole seeking to paint a rosy picture of sinking organizations (window dressing). Since the management accountant earns his income from the company (the employer), he has no choice other than to abuse the ethical concepts of his noble profession. In the same vein, because the auditor earns his fees from his client, and may want to keep and maintain his client, he equally yield to his client's request. Is this the right thing to do? The professional code of conduct stipulates that the professional accountant should resign his appointment or engagement when faced with such ethical dilemma. Donaldson (1996) identified pressure from employers and clients as the most prevalent factor influencing the adoption of accounting ethics by professional accountants.

One may think that professional accountants will do the right thing, regardless of the amount of personal sacrifice involved. But this is easier said than done. Frenchman (1998) suggested that in exhibiting ethical 
behaviour, professional accountants often come into conflict with their clients and or employers. This is because what the client or employer wants the accountant to do may be against his professional code of conduct. Knowing fully that resignation is the price that goes with his conflict of ethical conduct with his client and employer, the accountant has no choice than to abuse ethical concepts and remain on his job. Professional accountants in Nigeria are scared of losing their present jobs because of ethical conduct since they are not too sure of getting any new job elsewhere. But in developed countries where the rate of unemployment is very low, a professional accountant can resign from an employment or engagement that conflict with his professional code of conduct, and have a new job or engagement in a short time. The price of losing his job makes professional accountants in developing countries to exhibit unethical behaviour.

Every professional accountant comes from a particular society with diverse norms and standards. Cheng (2012) opined that the kind of societal values acquired by the accountant at early childhood have more influence on him than the professional code of conduct. Therefore, professional accountants allow their society values (good or bad) to interfere with their professional judgment in financial reporting. For example, a study conducted by Mamud (1999 as cited in Akenbor and Tennyson 2014) on "Career Choice" in the central district of Kano revealed that parents prefer their wards to study accounting because they believe that accountants are wealthy individuals. With this societal value built on the child, as he becomes a professional accountant he is bound to violate the accounting ethics so as to become wealthy.

A professional accountant may suspect that activities in which he or she is asked to participate are unethical, but had no complete information of the transactions. For example a chief accountant in a multinational oil company in Port Harcourt was asked to process the paper works to reimburse the manager of international operations for a $\$ 64,000$ "communication expenditure" claimed in the manager expense account. The accountant considers it improbable that the manager actually spent $\$ 64,000$ in personal funds for the company. More likely the accountant thinks the funds were paid as a bride to some foreign agencies. However, the accountant has no facts concerning the expenditure, but, the top management wants the international operations' manager reimbursed. In most situations, accountants have neither the responsibility nor the right to investigate their employers or clients. If a further investigation of the facts is not directly related to the accountant's professional responsibilities, the accountant simply may never have enough information to reach an informal decision as to whether or not specific activities are "ethical" (Frenchman, 1998).

No code of ethics can address every situation that might arise. Every "ethical dilemma" borders upon the unique, having its own facts and circumstances (Robert, 2005). In many situations, however the ethical course of action is not readily apparent. Assume that a professional accountant is auditing the financial statements of a company. During this audit, the company was acquired by another company. The chief executive of the acquired company, is a brother to the accountant (auditors). Has the accountant's independence been impaired with respect to the company's audit? Must the auditor resign from the engagement? This case is intended to show that ethical dilemmas do not always have clear-cut answers. This case hinges upon personal judgment, including the closeness of the relationship "between the accountant and the chief executive (brother)" and what impairs the "appearance" of independence. Thus, even with all the facts in hand, experts are likely to disagree on the answer to this case.

Codes of ethics, including the "official interpretations" typically do not address such specific questions. Therefore, it's often not possible to simply "lookup" the solution to an ethical problem. In deciding when an ethical problem exists, and in determining what constitutes ethical behaviour, the practitioner must often rely primarily upon his or her own professional judgment (Cheng, 2012).

In assessing the payoff of unethical behaviours of professional accountants, Robin (1989) affirmed that there are no concrete and conclusive proofs that companies where accountants exhibit ethical behaviours are more profitable. However Solomon (2002) reported that in the long-run ethical conduct has a positive effect on profitability, even though in certain circumstances, particularly in the short-run, unethical practice yield greater profits.

Other empirical studies conducted in Iran, Korea and Nigeria have also supported the theory of imperative principle mentioned earlier. Mahdi and Mohsen (2011) carried out a study on the impact of professional ethics on financial reporting quality in Iran. They employed a 24-item questionnaire and worked with a sample of 205 Iranian companies. The result of their findings showed that professional ethics have a significant impact on the quality of financial reporting.

Masoud and Mahbude (2013) investigated the impact of professional ethics on financial reporting quality and found that developing professional ethics in accounting will help promote financial reporting quality. Tae and Jinhan (2011) examined the effect of business ethics on financial reporting quality using Korea firms. They found out that companies with a higher level of ethical commitment are engaged in less earnings management, report earnings more conservatively, and predict future cash flows more accurately than those with a lower level of ethical commitment. We also find that corporate commitment to business ethics has perpetuating effects on future financial reporting quality. 
Ogbonna and Appah (2011) investigated the effect of ethics on financial reporting quality in Nigeria using a sample of 123 accountants. The study found out that ethical compliance by the accountant positively and significantly affects the quality financial reports. Flugrath, Bennie and Chen (2007) conducted a study on ethics and financial reporting quality using a sample of 112 professional accountants using primary data. The results indicate that the presence of ethics has a positive impact on the quality of the judgement made by professional accountants. Berrone, Suroca and Tribo (2005) carried out a study using 515 companies using OLS regression analysis. Their study revealed that a strong corporate ethical identity was positively related to high levels of stakeholder satisfaction. In turn stakeholder satisfaction had a positive influence on the financial performance of the firm.

The general ethical codes include confidentiality, integrity, transparency, accountability, competence, loyalty, honesty, anonymity, impartiality, courtesy and respect, neutrality and such other codes. Citing classical evidence in Nigeria, Sanusi (2010) notes that, financial institutions made public the information on their operations on a highly selective and biased basis and investors were unable to make informed decisions on the quality of their earnings, the strength of their balance sheets or the risks in their businesses. Without accurate information, investors made ill-advised decisions regarding stocks, enticed by a speculative market bubble which was allegedly partly fuelled by the banks through the practice of margin lending. Some banks even engaged in manipulating their books by colluding with other banks to artificially enhance financial positions and therefore stock prices. Practices such as converting non-performing loans into commercial papers and bank acceptances and setting up off-balance sheet special purpose vehicles to hide losses were prevalent. Recently the CBN put an end to these practices and the collapse of the equity markets effectively put an end to alleged stock price manipulation.

According to Egwuonwu (2007), there is a long list of corporate casualties across international divides on account of behavioural misalignments or diminished behavioural governance and accountability. In Nigeria alone 54 banks have either failed or forced to close and Cadbury Nigeria Plc. who overstated their earnings through the cooking of accounts and were appropriately sanctioned by the Security and Exchange Commission (SEC).Consequently, following these questionable accounting practices witnessed in the operations of these entities, the reputation and ethical values of the accounting Professional seems elusive. Although, accounting regulatory bodies intend that financial statements should be useful to a wide range of users. The preparers of those financial statements act as intermediaries between the regulators and the multiplicity of end users of the statements. They therefore occupy a powerful position as interpreters of the regulations, and, given the complexity of the business world, it is hard to see how some degree of ethical inconsistency can be avoided.

According to Amat and Gwothrope (2004), financial statements provide information that is used by interested parties to assess the performance of managers and to make economic decisions. Users may assume that the financial information they receive is reliable and fit for its purpose. Thus, accounting regulation attempts to ensure that information is produced on a consistent basis in accordance with a set of rules that make it reliable for users.

\section{Method}

The data used for this study were purely primary data. According to Mugenda (2003), Target Population is the specific population by which information is derived. The population of this study is the registered members of ICAN District Society in Calabar who may be part of the accounting unit of their various institutions, firms or who offer consultancy services. Stratified sampling involves the division of a population into smaller groups known as strata. The study employed stratified and simple random sampling techniques to develop the sample components. The goal of stratified random sampling is to achieve desired representation from various sub groups in the population. Due to large size of the target population, the researcher, 269 participants were accessible. Taro Yamane formula was used to arrive at the population sample of this study.

In carrying out this study, a total of one hundred and sixty one (161) copies of questionnaires were administered out of which 148 were filled and returned. The analysis was therefore based on the total of one hundred and forty eight (148) copies of valid questionnaire collected from registered members of the ICAN District Society in Calabar. A survey research design was adopted for the study. The study covered the staff of selected accounting firms within the Calabar metropolis and other accounting practitioners within Calabar.

$n=\frac{N}{1+N(e)^{2}}$

Where $\mathrm{n}=$ sample size, $\mathrm{N}=$ Population and $\mathrm{e}=$ level of significance or error limit. Substituting the accessible population size of 269 and level of significance of 0.05 into the formula above, we have: 


$$
\begin{aligned}
& n-\frac{269}{1+269(0.05)^{2}} \\
& -\mathrm{n}\left(1+269(0.05)^{2}\right)=269 \\
& =\mathrm{n}(1+0.6725)=269 \\
& =\mathrm{n}(1.6775)=269 \\
& =1.6725 \mathrm{n}=269 \\
& \mathrm{I}=\frac{269}{1.6725}=160.8=161 \text { Apprux }
\end{aligned}
$$

11.1 Validity and Reliability of Instrument: The questionnaires' validity was provided through adequate coverage

of the topic under investigation through the expert advice. A pre-test and post-test were carried out to test the reliability of the primary data collected for the study.

11.2 Model Specification: The relationship between these indices is shown by the model below:

$\begin{array}{lll}\begin{array}{ll}\text { ACCTP }=\beta_{0}+\beta_{1} \text { EINTG } \\ \text { Where }\end{array} & \beta_{2} \text { EOBJ }+\beta_{3} \text { EPROFB }+\beta_{4} \text { EPROFC }+\mathrm{e} \\ \text { ACCTP } & = & \text { Accounting Practice } \\ \text { EINTG } & = & \text { Ethics of Integrity } \\ \text { EOBJ } & = & \text { Ethics of Objectivity } \\ \text { EPROFB } & = & \text { Ethics of Professional Behaviour } \\ \text { EPROFC } & = & \text { Error term } \\ \mathrm{e} & = & \text { Intercept } \\ \beta_{0} & = & \text { Coefficient } \\ \beta & \end{array}$

11.3Method of Data Analysis: The data obtained for the study will be analysed using Multiple Regression

Technique, this technique will show the relationship between the independent variables and the dependent variable thus providing a basis for hypotheses testing.

\section{RESULTS}

The presentation, analysis and interpretation of the data collected for this research work are indicated below. It highlights both the mathematical and statistical techniques adopted in testing the research hypothesis of the study which sought to investigate the effect of ethical thoughts in accounting on accounting practice.

Normality test was carried out to check if data were normal. This was done using skewness and kurtosis. According to Hair et al (2010), data is normal when the Z-statistic for skewness and kurtosis when calculated is less than or equal to \pm 2.58 . Z- skewness or Z-kurtosis value is obtained by dividing the statistics by the standard error as shown in the descriptive statistics on Table .... Below. Hence from the table, data for the study is normal since the Z-skewness or Z-kurtosis value were less than \pm 2.58 . 
Table 1

Descriptive Statistics

\begin{tabular}{|l|r|r|r|r|r|r|r|r|r|}
\hline & \multicolumn{1}{|c|}{$\mathrm{N}$} & \multicolumn{1}{c|}{ Minimum } & \multicolumn{1}{c|}{ Maximum } & \multicolumn{1}{c|}{ Mean } & \multicolumn{1}{c|}{ Std. Deviation } & \multicolumn{2}{|c|}{ Skewness } & \multicolumn{2}{|c|}{ Kurtosis } \\
\cline { 2 - 10 } & Statistic & \multicolumn{1}{c|}{ Statistic } & \multicolumn{1}{c|}{ Statistic } & \multicolumn{1}{c|}{ Statistic } & \multicolumn{1}{c|}{ Statistic } & Statistic & Std. Error & Statistic & Std. Error \\
\hline ACCTP & 148 & 2.00 & 8.00 & 5.7635 & 1.25281 & -.384 & .199 & -.894 & .396 \\
EINTG & 148 & 15 & 20 & 16.42 & 1.050 & .521 & .199 & .217 & .396 \\
EOBJ & 148 & 15 & 20 & 16.30 & 1.193 & .511 & .199 & -.544 & .396 \\
EPROFB & 148 & 15 & 19 & 16.01 & .979 & .603 & .199 & -.515 & .396 \\
EPROFC & 148 & 12 & 19 & 16.18 & 1.278 & .366 & .199 & -.203 & .396 \\
Valid N (listwise) & 148 & & & & & & & & \\
\hline
\end{tabular}

For instance:

Skewness Z-statistic $\quad-\underline{0.394}$

$$
0.199=-1.98
$$

Kurtosis Z-statistic $\quad \underline{-0.894}$

$$
\overline{0.396}=-1.11
$$

12.1 Linearity: Linearity was assessed using the correlation analysis as shown in Table 4.4 below. From the result on the table, all the variables have a moderate and positive relationship with each other. Hence linearity is established. Also, from the regression table, tolerance and VIF showed that there was no problem of multicolinearity.

Table 2

\section{Correlations}

\begin{tabular}{|ll|r|r|r|r|r|}
\hline & & \multicolumn{1}{|c|}{ ACCTP } & \multicolumn{1}{|c|}{ EINTG } & EOBJ & EPROFC & EPROFB \\
\hline Pearson Correlation & ACCTP & 1.000 & -.457 & -.775 & -.610 & -.254 \\
& EINTG & -.457 & 1.000 & .413 & .247 & .024 \\
& EOBJ & -.775 & .413 & 1.000 & .619 & .155 \\
& EPROFC & -.610 & .247 & .619 & 1.000 & .113 \\
& EPROFB & -.254 & .024 & .155 & .113 & 1.000 \\
\hline Sig. (1-tailed) & ACCTP &. & .000 & .000 & .000 & .001 \\
& EINTG & .000 &. & .000 & .001 & .388 \\
& EOBJ & .000 & .000 & & .000 & .030 \\
& EPROFC & .000 & .001 & .000 &. & .085 \\
& EPROFB & .001 & .388 & .030 & .085 &. \\
\hline $\mathrm{N}$ & ACCTP & 148 & 148 & 148 & 148 & 148 \\
& EINTG & 148 & 148 & 148 & 148 & 148 \\
& EOBJ & 148 & 148 & 148 & 148 & 148 \\
& EPROFC & 148 & 148 & 148 & 148 & 148 \\
& EPROFB & 148 & 148 & 148 & 148 & 148 \\
\hline
\end{tabular}

\subsection{Multi-colinearity}

Multi co-linearity is the condition in which one or more independent variables can be expressed as a linear combination of other independent variables. This test is used to determine whether the correlation between the independent variables. If there is a correlation then there is a problem called multi- colineraity. To detect the multi co-linearity, we use variance inflation factor (VIF) and tolerance for each independent variable. The limit value of tolerance and VIF limit is 10' (Ghozali, 2006: 92).

The calculation result output co-efficient VIF shows that all independent variables have a value of VIF more than 0.1 and VIF value of each variable is not more than 10. It can be concluded that, there is no multi colinearity between the independent variables in this study. 


\subsection{Test of Multi co-linearity}

Table 3

\begin{tabular}{|l|l|l|l|}
\hline \multicolumn{2}{|l|}{ Model } & \multicolumn{2}{|l|}{ Collinearity Statistics } \\
\cline { 3 - 4 } \multicolumn{1}{l|}{} & Tolerance & VIF \\
\hline \multirow{3}{*}{1} & (Constant) & & \\
& EINTG & .827 & 1.209 \\
& EOBJ & .537 & 1.863 \\
& EPROFC & .616 & 1.623 \\
\hline & EPROFB & .973 & 1.027 \\
\hline
\end{tabular}

\subsection{Reliability Analysis}

Test retest was used to ascertain the reliability of the instrument. Test Retest reliability measures test consistency. This is the reliability of a test measured over time. In other words, give the same test twice to the same people at different times to see if the scores are the same. The pre-test and post-test were issued within a month interval. The results are shown in table 4.

The Pearson correlation coefficients and $p$-value were;
ACCTP
0.713 and 0.000
EINTG:
0.768 and 0.000
EOBJ:
0.947 and 0.000
EPROFB:
0.937 and 0.000
EPROFC:
0.982 and 0.000

This indicates the evidence of test-retest reliability.

Table 4

\begin{tabular}{|c|c|c|c|c|c|c|c|c|c|c|c|}
\hline \multicolumn{12}{|c|}{ Correlations } \\
\hline & & ACCTP & EINTG & EOBJ & EPROFB & EPROFC & RetestACCTP & RetestEINTG & RetestEOBJ & $\begin{array}{c}\text { RetestEPROF } \\
\text { B }\end{array}$ & $\begin{array}{c}\text { RetestEPROF } \\
\mathrm{C}\end{array}$ \\
\hline \multirow[t]{3}{*}{ ACCTP } & Pearson Correlation & 1 & $-.457^{\prime \prime \prime}$ & $-.775^{\prime \prime}$ & $-.254^{\prime \prime \prime}$ & $-.610^{\prime \prime}$ & $.713^{\prime \prime}$ & $-.346^{\prime \prime}$ & $-.715^{\prime \prime}$ & -.211 & $-.588^{\prime \prime}$ \\
\hline & Sig. (2-tailed) & & .000 & .000 & .002 & .000 & .000 & .000 & .000 & .010 & .000 \\
\hline & $\mathrm{N}$ & 148 & 148 & 148 & 148 & 148 & 148 & 148 & 148 & 148 & 148 \\
\hline \multirow[t]{3}{*}{ EINTG } & Pearson Correlation & $-.457^{\prime \prime}$ & 1 & $.413^{\prime \prime}$ & .024 & $.247^{\prime \prime}$ & $-.482^{\prime \prime \prime}$ & $.768^{\prime \prime}$ & $.344^{\prime \prime}$ & -.054 & $.233^{\prime \prime \prime}$ \\
\hline & Sig. (2-tailed) & .000 & & .000 & .775 & .002 & .000 & .000 & .000 & .516 & .004 \\
\hline & $\mathrm{N}$ & 148 & 148 & 148 & 148 & 148 & 148 & 148 & 148 & 148 & 148 \\
\hline \multirow[t]{3}{*}{ EOBJ } & Pearson Correlation & $-.775^{\prime \prime \prime}$ & $.413^{11}$ & 1 & .155 & $.619^{\prime \prime \prime}$ & $-.618^{\prime \prime \prime}$ & $.337^{\prime \prime \prime}$ & $.947^{\prime \prime}$ & .130 & $.598^{\prime \prime \prime}$ \\
\hline & Sig. (2-tailed) & .000 & .000 & & .059 & .000 & .000 & .000 & .000 & .116 & .000 \\
\hline & $\mathrm{N}$ & 148 & 148 & 148 & 148 & 148 & 148 & 148 & 148 & 148 & 148 \\
\hline \multirow[t]{3}{*}{ EPROFB } & Pearson Correlation & $-.254^{\prime \prime \prime}$ & .024 & .155 & 1 & .113 & -.148 & -.079 & .143 & $.937^{\prime \prime}$ & .108 \\
\hline & Sig. (2-tailed) & .002 & .775 & .059 & & .171 & .074 & .341 & .083 & .000 & .191 \\
\hline & $\mathrm{N}$ & 148 & 148 & 148 & 148 & 148 & 148 & 148 & 148 & 148 & 148 \\
\hline \multirow[t]{3}{*}{ EPROFC } & Pearson Correlation & $-.610^{\prime \prime}$ & $.247^{\prime \prime}$ & $.619^{\prime \prime}$ & .113 & 1 & $-.454^{\prime \prime}$ & $.201^{\circ}$ & $.581^{\prime \prime}$ & .062 & $.982^{\prime \prime}$ \\
\hline & Sig. (2-tailed) & .000 & .002 & .000 & .171 & & .000 & .014 & .000 & .456 & .000 \\
\hline & $\mathrm{N}$ & 148 & 148 & 148 & 148 & 148 & 148 & 148 & 148 & 148 & 148 \\
\hline \multirow[t]{3}{*}{ RetestACCTP } & Pearson Correlation & $.713^{\mathrm{m}}$ & $-.482^{\prime \prime}$ & $-.618^{\prime \prime}$ & -.148 & $-.454^{\prime \prime}$ & 1 & $-.334^{\prime \prime \prime}$ & $-.579^{\prime \prime}$ & -.115 & $-.438^{\prime \prime \prime}$ \\
\hline & Sig. (2-tailed) & .000 & .000 & .000 & .074 & .000 & & .000 & .000 & .165 & .000 \\
\hline & $\mathrm{N}$ & 148 & 148 & 148 & 148 & 148 & 148 & 148 & 148 & 148 & 148 \\
\hline \multirow[t]{3}{*}{ RetestEINTG } & Pearson Correlation & $-.346^{\prime \prime \prime}$ & $.768^{\prime \prime}$ & $.337^{\prime \prime}$ & -.079 & $.201^{1}$ & $-.334^{\prime \prime}$ & 1 & $.325^{\prime \prime}$ & -.081 & $.192^{\circ}$ \\
\hline & Sig. (2-tailed) & .000 & .000 & .000 & .341 & .014 & .000 & & .000 & .329 & .019 \\
\hline & $\mathrm{N}$ & 148 & 148 & 148 & 148 & 148 & 148 & 148 & 148 & 148 & 148 \\
\hline \multirow[t]{3}{*}{ RetestEOBJ } & Pearson Correlation & $-.715^{\prime \prime}$ & $.344^{\prime \prime \prime}$ & $.947^{\prime \prime}$ & .143 & $.581^{\prime \prime}$ & $-.579^{\prime \prime \prime}$ & $.325^{\prime \prime}$ & 1 & .161 & $.561^{\prime \prime}$ \\
\hline & Sig. (2-tailed) & .000 & .000 & .000 & .083 & .000 & .000 & .000 & & .050 & .000 \\
\hline & $\mathrm{N}$ & 148 & 148 & 148 & 148 & 148 & 148 & 148 & 148 & 148 & 148 \\
\hline \multirow[t]{3}{*}{ RetestEPROFB } & Pearson Correlation & $-.211^{\prime}$ & -.054 & .130 & $.937^{\prime \prime}$ & .062 & -.115 & -.081 & .161 & 1 & .058 \\
\hline & Sig. (2-tailed) & .010 & .516 & .116 & .000 & .456 & .165 & .329 & .050 & & .484 \\
\hline & $\mathrm{N}$ & 148 & 148 & 148 & 148 & 148 & 148 & 148 & 148 & 148 & 148 \\
\hline \multirow[t]{3}{*}{ RetestEPROFC } & Pearson Correlation & $-.588^{\prime \prime \prime}$ & $.233^{11}$ & $.598^{\prime \prime}$ & .108 & $.982^{\prime \prime \prime}$ & $-.438^{\prime \prime \prime}$ & $.192^{n}$ & $.561^{\prime \prime}$ & .058 & 1 \\
\hline & Sig. (2-tailed) & .000 & .004 & .000 & .191 & .000 & .000 & .019 & .000 & .484 & \\
\hline & $\mathrm{N}$ & 148 & 148 & 148 & 148 & 148 & 148 & 148 & 148 & 148 & 148 \\
\hline
\end{tabular}

Multiple regression technique was adopted to examine the relationship amongst the variables. Table shows the regression result. 
Table 5

\begin{tabular}{|c|c|c|c|c|c|c|c|c|}
\hline \multicolumn{9}{|c|}{ Coefficients $^{a}$} \\
\hline \multirow[b]{2}{*}{ Mod } & & \multicolumn{2}{|c|}{ Unstandardized Coefficients } & \multirow{2}{*}{$\begin{array}{c}\text { Standardized } \\
\text { Coefficients }\end{array}$} & \multirow[b]{2}{*}{$t$} & \multirow[b]{2}{*}{ Sig. } & \multicolumn{2}{|c|}{ Collinearity Statistics } \\
\hline & & B & Std. Error & & & & Tolerance & VIF \\
\hline \multirow[t]{5}{*}{1} & (Constant) & 24.808 & 1.419 & & 17.482 & .000 & & \\
\hline & EINTG & -.207 & .063 & -.174 & -3.291 & .001 & .827 & 1.209 \\
\hline & EOBJ & -.579 & .069 & -.552 & -8.421 & .000 & .537 & 1.863 \\
\hline & EPROFC & -.206 & .060 & -.210 & -3.434 & .001 & .616 & 1.623 \\
\hline & EPROFB & -.179 & .062 & -.140 & -2.881 & .005 & .973 & 1.027 \\
\hline
\end{tabular}

a. Dependent Variable: ACCTP

From the above table, the regression line can be depicted as; $\mathrm{ACCTP}=24.808-0.207 \mathrm{EINTG}-0.579 \mathrm{EOBJ}-0179 \mathrm{EPROFB}-0.206 \mathrm{EPROFC} \pm \mathrm{e}$

Where:

ACCTP - Accounting Practice

EINTG - Ethics of Integrity

EOBJ - Ethics of Objectivity

EPROFB - Ethics of Professional Behaviour

EPROFC - Ethics of Professional Competence

\pm - $\quad$ Standard Sample Error

24.808 represents the slope of the regression line, that is, when all explanatory variables (EINTG, EOBJ, EPROFB and EPROFC) are held constant, all things being equal, ACCTP is subject to vary by 24.808 .

-0.207EINTG represents the co-efficient of EINTG which is negative, indicating that it has a negative direct relationship with ACCTP. This depicts that a percentage increase in EINTG, results in a 20.7 percent decrease in ACCTP. Likewise, when there is a percentage decrease in EINTG, it will result in a 20.7 percent increase in ACCTP.

The -0.579EOBJ represents the co-efficient of EOBJ which is negative, indicating a negative relationship with ACCTP. This depicts that a percentage increase in EOBJ will result to a 57.9 percent decrease in ACCTP. Likewise, when there is a percentage decrease in EOBJ, it will result in a 57.9 percent increase in ACCTP.

The $-0.179 E P R O F B$ represents the co-efficient of EPROFB which is negative, indicating a negative relationship with ACCTP. This depicts that a percentage increase in EPROFB will result to a 17.9 percent decrease in ACCTP. However, when there is a percentage decrease in EPROFB, it will result in a 17.9 percent increase in ACCTP.

The -0.206EPROFC represents the co-efficient of EPROFC which is negative, indicating a negative relationship with ACCTP. This depicts that a percentage increase in EPROFC will result to a 20.6 percent decrease in ACCTP. Likewise, a percentage decrease in EPROFC will in turn result to a 20.6 percent increase in ACCTP.

$\pm \mathrm{e}-$ represent the standard sample error which depicts that there are many other explanatory variables that influences ACCTP that were not captured in the regression line. In addition, the co-linearity test was carried out and tolerance value for all independent variables was less than one (1). Also, their VIF is less than 10.

The multiple correlation co-efficient $(\mathrm{R})$ is 0.819 . This indicates that there is a strong relationship amongst the variables under study.

The co-efficient of determination $\left(\mathrm{R}^{2}\right)$ shows to what extent the independent variables are able to explain the variation in the dependent variable. The co-efficient of determination $\left(\mathrm{R}^{2}\right)$ is 0.671

$$
\begin{aligned}
\mathrm{R}^{2} & =0.671 \times 100 \% \\
& =67.1 \%
\end{aligned}
$$

This depicts that the independent variables (EINTG, EOBJ, EPROFB and EPROFC) capture 67.1 percent of the total variation (100 percent) in the dependent variable (ACCTP). In other words, the independent variables (EINTG, EOBJ, EPROFB and EPROFC) explained 67.1 percent out of 100 percent variation that occurred in the dependent variable (ACCTP).

The remaining percent (i.e 32.9 percent) represents the unexplained percentage and accounts for other independent variables that were not in the multiple regression line (model).

In addition to the co-efficient of determination in the Adjusted $\mathrm{R}^{2}$ and Durbin Watson, the Adjusted $\mathrm{R}^{2}$ shows that if an independent variable with the least co-efficient (Say EPROFB with -0.179 co-efficient) is dropped from the regression line, the remaining independent variables EINTG, EOBJ and EPROFC can still explain the variation in ACCTP (dependent variable) to an extent of 66.1 percent. 
Based on the results of testing against the values obtained, using Durbin Watson Statistics (1.959), we can conclude that there is no auto - correlation. The table below shows the aforementioned:

Table 6

\begin{tabular}{|c|c|c|c|c|c|c|c|c|c|c|}
\hline \multirow[b]{3}{*}{ Model } & \multicolumn{9}{|c|}{ Model Summary } & \multirow[b]{3}{*}{$\begin{array}{l}\text { Durbin- } \\
\text { Watson }\end{array}$} \\
\hline & \multirow[b]{2}{*}{ R } & \multirow[b]{2}{*}{ R Square } & \multirow[b]{2}{*}{$\begin{array}{l}\text { Adjusted R } \\
\text { Square }\end{array}$} & \multirow[b]{2}{*}{$\begin{array}{l}\text { Std. Error of } \\
\text { the Estimate }\end{array}$} & \multicolumn{5}{|c|}{ Change Statistics } & \\
\hline & & & & & $\begin{array}{c}\text { R Square } \\
\text { Change }\end{array}$ & F Change & df1 & $d f 2$ & Sig. F Change & \\
\hline 1 & $.819^{\mathrm{a}}$ & .671 & .661 & .72898 & .671 & 72.793 & 4 & 143 & .000 & 1.959 \\
\hline
\end{tabular}

a. Predictors: (Constant), EPROFB, EINTG, EPROFC, EOBJ

b. Dependent Variable: ACCTP

In addition to the above, a test on statistical significance of the overall variable in the model was carried out. This is shown on the table

Table 7

ANOVA $^{\text {a }}$

\begin{tabular}{|ll|r|r|r|r|r|}
\hline \multicolumn{1}{|c|}{} & \multicolumn{1}{c|}{$\begin{array}{c}\text { Sum of } \\
\text { Model }\end{array}$} & Squares & df & Mean Square & \multicolumn{1}{c|}{ F } & Sig. \\
\hline 1 & Regression & 154.731 & 4 & 38.683 & 72.793 & $.000^{\text {b }}$ \\
& Residual & 75.992 & 143 & .531 & & \\
& Total & 230.723 & 147 & & & \\
\hline
\end{tabular}

a. Dependent Variable: ACCTP

b. Predictors: (Constant), EPROFB, EINTG, EPROFC, EOBJ

From the ANOVA table, the significant value (0.000) is less than 0.05; hence, the explained variables (EINTG, EOBJ, EPROFB and EPROFC) in the model predict the ACCTP. This also means that the data is a good fit for the study.

\subsection{Test of hypotheses}

There is a need to test for the significance of the independent variables (EINTG, EOBJ, EPROFB and EPROFC) and the dependent variable (ACCTP). In doing this, a 5\% level of significance was adopted.

12.5.1 Hypothesis One:

$\mathrm{H}_{0}$ : There is no significant relationship between ethics of integrity and accounting practice.

$\mathrm{H}_{1}$ : There is a significant relationship between ethics of integrity and accounting practice.

From the table the significant value EINTG (0.001) is less than 0.05, hence the null hypothesis is rejected and the alternative hypothesis is accepted. We can now conclude that ethics of integrity has a significant relationship with accounting practice.

\subsubsection{Hypothesis Two:}

$\mathrm{H}_{0}$ : There is no significant relationship between ethics of objectivity and accounting practice.

$\mathrm{H}_{1}$ : There is a significant relationship between ethics of objectivity and accounting practice.

From the table the significant value EOBJ (0.00) is less than 0.05 , hence the null hypothesis is rejected and the alternative hypothesis is accepted. We can now conclude that ethics of integrity has a significant relationship with accounting practice.

\subsubsection{Hypothesis Three:}

$\mathrm{H}_{0}$ : There is no significant relationship between ethics of professional behaviour and accounting practice.

$\mathrm{H}_{1}$ : There is a significant relationship between ethics of professional behaviour and accounting practice.

From the table the significant value EPROFB (0.005) is less than to 0.05 , hence the null hypothesis is rejected and the alternative hypothesis is accepted. We can now conclude that ethics of professional behaviour has a significant relationship with accounting practice. 


\subsubsection{Hypothesis Four:}

$\mathrm{H}_{0}$ : There is no significant relationship between ethics of professional competence and accounting practice.

$\mathrm{H}_{1}$ : There is a significant relationship between ethics of professional competence and accounting practice.

From the table the significant value EPROFC (0.001) is less than to 0.05 , hence the null hypothesis is rejected and the alternative hypothesis is accepted. We can now conclude that ethic of professional competence and due care has a significant relationship with accounting practice.

\section{Discussion of findings}

13.1 Ethics of integrity and accounting practice: The findings from the regression result indicated that the ethics of integrity has a negative relationship with accounting practice. Further test carried to test for the significance of this relationship and findings revealed that ethics of integrity has a significant relationship with accounting practice. This implies that when professional accountants imbibe the ethics of integrity, it will lead to an efficient and effective accounting practice which detects and minimizes fraud and error when they occur.

13.2 Ethics of objectivity and accounting practice: The findings from the regression result indicated that ethics of objectivity has a negative relationship with accounting practice. Further test carried to test for the significance of this relationship and findings revealed that the ethics of objectivity has a significant relationship with accounting practice. This is an indicator that if professional accountants are more objective in the discharge of their duties, it will result to a better, more efficient and effective accounting practice that is without undue preference to neither party of the management or its stakeholders.

13.3Ethics of confidentiality and accounting practice: The findings from the regression result indicated that the ethics of professional behaviour has a negative relationship with accounting practice. Further test carried to test for the significance of this relationship and findings revealed that the ethics of professional behaviour has a significant relationship with accounting practice. This means that faithful adherence to the ethics of professional behaviour within acceptable bounds under the law will result in better accounting practice.

13.4Ethics of professional competence and accounting practice: The findings from the regression result indicated that the ethics of professional competence and due care has a negative relationship with accounting practice. Further test carried to test for the significance of this relationship and findings revealed that the ethics of professional competence and due care has a significant relationship with accounting practice. This means that faithful compliance to the ethics of professional competence and due care in keeping with the recent developments within the accounting profession will positively impact accounting practice and boost performance with regards to expert services and consultancy.

\section{Contribution to knowledge}

This study has added to the existing body of knowledge in three ways: (1) Disclosure of the societal believe in Nigeria that becoming wealthy is the sole objective of taking up a career in accountancy. (2) The high level of unemployment in Nigeria being the reason why professional accountants cannot resign when their employers or clients want them to act contrary to their professional code of conduct and. (3) It is unthinkable and unlikely that the professional accountant will always do the right thing regardless of the amount of personal sacrifice involved.

\section{Summary of Findings and Conclusion}

Ethics of Integrity, ethics of objectivity, ethics of professional behaviour and ethics of professional competence/due care all have negative relationships with accounting practice and these relationships were significant at the alpha level of .05 (i.e. $95 \%$ of being true). The meaning of these negative relationships is that as the application of ethical thoughts increases, non-occurrence of corporate frauds or scandals (accounting practice) decreases (i.e. corporate frauds or scandals still occur). This finding or discovery is therefore, in support of the argument or thesis statement of this research. The information requirements and environments under which financial reporting is made is both very complex and challenging. It is complex to the extent that there is the likelihood that a conflict of interest might arise due to the multiplicity of end users of accounting information. Consequently, the continuum of interested parties; Management, shareholders, creditors, employees amongst others puts the financial statement and its preparers in a complex environment. Our emphasis on the role of accounting practice in restoring systemic confidence in financial estimates is borne out of the fact that the statutory roles of the accounting professional either as a company staff, internal auditor or external auditor, positions the accountant as an interface between the reports of corporate entities and the confidence of users of such information. 


\section{Recommendations and Direction for Future Research}

Based on the findings of this study, the following are recommended:

Board of Directors and Audit Committees should be made up of people with corporate experience, proven integrity and financial expertise. Corporate Affairs Commission (CAC), the Securities and Exchange Commission (SEC), the Central Bank of Nigeria (CBN) and other relevant federal regulatory agencies should ensure the enforcement of their various rules, ethical codes and codes of corporate governance as applicable to company directors. There should be an upward review of fines imposed by CAMA 2004 for breach of fiduciary duty by directors.

Auditors must adhere to the fundamentals of professional code of conduct such as integrity, objectivity and independence, due care and public interest.

Each organization in Nigeria should establish ethics departments to ensure that activities are in line with the codes of ethics applicable to the financial reporting process.

Professional accountants who are custodians and producers of accounting information should adhere to the codes of professional best practices issued by relevant professional bodies.

Greater efforts should be made by the relevant professional bodies to review their various ethical codes guiding members' conduct or behaviour in practice. Widespread enlightenment coupled with stiffer penalties for professional misconduct could also be a way out.

The study should also be extended to the effect of ethics of client's confidentiality on accounting practice.

\section{Acknowledgements}

We acknowledge the assistance of some key members of the Institute of Chartered Accountants of Nigeria (ICAN) District Society, Calabar Chapter. They provided useful information and research materials.

\section{REFERENCES}

Akenbor, C. O. \& Tennyson, O. (2014). Ethics of accounting profession in Nigeria. Journal of Business and Economics, 5(8), 1374-1382.

Amat, S, \& Gwothrope, J. (2004). Boards of directors and corporate financial performance: a review and integrative model. Journal of Management, 15(2), 291-334

Aquack T. A. \& Lipe R. T. (2010). Re-examining the accounting ethics, Journal of Business Ethics, 18(2) 114128.

Berrone, P., Suroca, J. \& Tribo, J. A. (2005). Corporate ethical identity as determinants of firms performance: A test of the mediating role of stakeholders satisfaction. Working Paper 05-31, Business School Series University of Madrid, Spain, Retrieved from: www.docbib.uc3m.es/workingpapers/wm.

CAMA (1990). Companies and Allied Matters Act as amended 2004 LFN

Cheng V. R. (2012). Why we are unethical in accounting practices, Finland: University of Turku Press.

Donaldson T. (1996). Issues in moral philosophy, New York: McGraw-Hills.

Egwuonwu, P. (2007). Financial reporting: the theoretical and regulatory framework (2 ${ }^{\text {nd }}$ ed.) Lagos: Oladimeji Publishers LTD

Flugrath, R. G., Bennie-Martineou and L. Chen, (2007). The impact of codes of ethics and experience on auditor's judgement. Management Financial Journal 22(6): 566-589.

Frenchman E. R. (1998). Corporate strategy and the search for ethics, Englewood Cliffs; New Jersey: PrenticeHall.

Hair, J. F., Black, W. C., Babin, B. J. \& Anderson, R. E. (2010). Multivariate data analysis (7 $7^{\text {th }}$ ed.). New York: Pearson.

Mahdi. M., \& Moshen, K. (2011). The impact of professional ethics on financial reporting quality. Australian Journal of Basic and Applied Research, 5(11), 2092-2096.

Masoud. B. \& Mahbube, A. (2013). Impact of professional ethics on financial reporting quality. American Eurasian Network for Scientific Information, 7(10), 2862-2866

Mautz, R. K. (1988). Editorial: Monuments, mistakes and opportunities. Accounting Horizons, 2(2), 123 -

Meckling, W. H., \& Jensen, M. C. (1976). Theory of the Firm: Managerial behavior, agency costs and ownership structure in Michael, C. Jensen (Eds.) Firm: Governance, Residual Claims and Organizational Forms, Harvard University Press. A Theory of the International Journal of Business Research and Management (IJBRM), 1(3), 201247.

Mugenda, O. M., \& Mugenda, A. G. (2003). Research methods: Qualitative and quantitative approaches. Nairobi: Africa Center for Technology Studies (ACTS) Press.

Nigam R. (2008). The relationship between professional ethics and corporate profitability, International Journal of Business Studies, 13(1) 217-229. 
Nwagboso, J. (2008). Professional ethics, skill and standards. Jos: Inspirations Media.

Ogbonna, G. N. \& Appah, E. (2011). Ethical compliance by the accountant on the quality of financial reporting and performance of quoted companies in Nigeria. Asian Journal of Business Management, 3(3), $152-$ 160.

Robert D. (2005). Professional ethics, Accounting Society, 11(1) 141-157.

Robertson, J. C. \& Louwers J.J (2002). Auditing and assurance services, (10 ${ }^{\text {th }}$ ed). New York: McGrawHill/Irwin Companies Inc.

Robin D. P. (1989). Business Ethics: Where profits meet value system, Englewood Cliffs; New Jersey: Prentice Hall.

Sanusi, L. S (2010, February 26). The nigerian banking industry: what went wrong and the way forward. The Convocation Square, Bayero University, Kano.

Skye Bank - The rise, the fall, the bridge to understand what happened on the 21/09/18. Before the acquisition of $M B L$, during the acquisition of $M B L$ and after the acquisition of MBL.http://threadreaderapp.com/thread/1044278537333731328.html.

Skye Bank - The rise, the fall and the bridge. Http://Www.Proshareng.Com/News/REGULATORS/SkyeBankthe rise-the fall-and-the Bridge/41946.

Solomon R. C. (2002). Ethics and excellence. New York: Oxford University Press.

Tae, H. C., \& Jinhan, P. (2011). Business ethics and financial reporting quality: evidence from Korea. Journal of Business Ethics 103(4), 403-427

\section{SECTION A: BIO DATA}

1. Sex: Male [ ] Female [ ]

2. Age: Below 25 years [ ] Between 26 and 35 years [ ] Between 36 and

45 years [ ] 46 and above [ ]

3. Educational Qualification: WAEC/GCE/NECO [ ] OND/NCE [ ]

HND/B.SC [ ] M.SC/MBA/PHD [ ]

4. Professional Qualification: CNA/ACA [ ] FCCA/FCA [ ] Others [ ]

5. Working Experience: 1-5 [ ] 6-10 [ ] 11-15 [ ] 16 and above [ ]

6. Designation: Financial Accountant [ ] Management Accountant [ ]

SECTION B

Tax Accountant [ ] Auditor [ ]

Below are a list of statements that may ascertain your assessment on the effect of ethical thoughts in accounting and its effect on accounting practice. Kindly indicate to what extent you agree or disagree with the statement using the following;

SA Strongly Agree

A Agree

UD Undecided

D Disagree

SD Strongly Disagree

\begin{tabular}{|c|c|c|c|c|c|c|}
\hline & Accounting Practice & $\mathrm{SA}$ & $\mathrm{A}$ & UD & $\mathrm{D}$ & SD \\
\hline 1 & $\begin{array}{l}\text { My organisation requests' employees to record purchases or expenditure or sales } \\
\text { that never occurred }\end{array}$ & & & & & \\
\hline 2 & $\begin{array}{l}\text { My organization requests employees to produce misleading projected figures to } \\
\text { obtain additional finance or loan. }\end{array}$ & & & & & \\
\hline 3 & My organisation rrequests employees to manipulate tax returns & & & & & \\
\hline 4 & $\begin{array}{l}\text { My organization requests employees to produce figures to mislead shareholders, } \\
\text { e.g. participation in the production of false and misleading financial statements; }\end{array}$ & & & & & \\
\hline
\end{tabular}

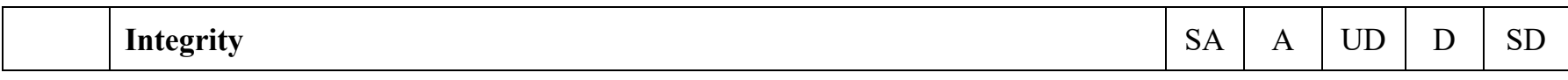




\begin{tabular}{|c|c|c|c|c|c|c|}
\hline & Professional Competence and Due care & SA & A & UD & $\mathrm{D}$ & SD \\
\hline 17 & $\begin{array}{l}\text { In my opinion, the level of expertise an accountant possesses determines the } \\
\text { quality of service provided. }\end{array}$ & & & & & \\
\hline 18 & In my experience, exercising due care positively influences accounting practice. & & & & & \\
\hline 19 & Negligence by the accounting practitioner bears its consequence. & & & & & \\
\hline 20 & $\begin{array}{l}\text { I believe that staying up to date with recent developments within the profession } \\
\text { is of use to ethical accounting practice. }\end{array}$ & & & & & \\
\hline 5 & $\begin{array}{l}\text { In my firm adherence to high ethical standards helps boost the integrity of } \\
\text { financial statements. }\end{array}$ & & & & & \\
\hline 6 & $\begin{array}{l}\text { In my firm acceptance of gift items by professional accountants affects the } \\
\text { integrity of an audit. }\end{array}$ & & & & & \\
\hline 7 & $\begin{array}{l}\text { In my opinion the value system of professional accountants affects the } \\
\text { presentation of financial statement. }\end{array}$ & & & & & \\
\hline \multirow[t]{2}{*}{8} & $\begin{array}{l}\text { In my organisation ethical standards are duly observed in the presentation of } \\
\text { financial statement of Nigerian firms. }\end{array}$ & & & & & \\
\hline & Objectivity & SA & A & UD & $\mathrm{D}$ & $\mathrm{SD}$ \\
\hline 9 & $\begin{array}{l}\text { In my firm the objective presentation of financial statements is affected by } \\
\text { ethical values prevalent in an organization }\end{array}$ & & & & & \\
\hline 10 & $\begin{array}{l}\text { In my firm the existence of an ethical committee in an organization positively } \\
\text { influences financial report integrity. }\end{array}$ & & & & & \\
\hline 11 & $\begin{array}{l}\text { In my opinion financial statements should be prepared and presented in } \\
\text { accordance with ethical guidelines within the organization }\end{array}$ & & & & & \\
\hline \multirow[t]{2}{*}{12} & $\begin{array}{l}\text { In my firm professional accountants are always objective in the preparation of } \\
\text { financial statements. }\end{array}$ & & & & & \\
\hline & Professional Behaviour & SA & A & UD & $\mathrm{D}$ & $\mathrm{SD}$ \\
\hline 13 & $\begin{array}{l}\text { In my organisation adherence to statutory regulations governing the profession } \\
\text { improves accounting practice. }\end{array}$ & & & & & \\
\hline 14 & $\begin{array}{l}\text { Indulging in prohibited acts or services negatively affects general perception on } \\
\text { the credibility of accounting products such as financial statements. }\end{array}$ & & & & & \\
\hline 15 & $\begin{array}{l}\text { In my opinion, law abiding professional accountants will clearly disclose } \\
\text { financial transactions in line with statutory requirements. }\end{array}$ & & & & & \\
\hline 16 & $\begin{array}{l}\text { I believe that the ethics of professional behaviour positively influences } \\
\text { accounting practice. }\end{array}$ & & & & & \\
\hline
\end{tabular}




\section{Descriptive}

Descriptive Statistics

\begin{tabular}{|l|r|r|r|r|r|r|r|}
\hline & \multicolumn{1}{|c|}{$\mathrm{N}$} & Minimum & Maximum & \multicolumn{1}{c|}{ Mean } & Std. Deviation & \multicolumn{2}{|c|}{ Skewness } \\
\cline { 2 - 8 } & Statistic & Statistic & Statistic & Statistic & Statistic & Statistic & Std. Error \\
\hline ACCTP & 148 & 2.00 & 8.00 & 5.7635 & 1.25281 & -.384 & .199 \\
EINTG & 148 & 15 & 20 & 16.42 & 1.050 & .521 & .199 \\
EOBJ & 148 & 15 & 20 & 16.30 & 1.193 & .511 & .199 \\
EPROFB & 148 & 15 & 19 & 16.01 & .979 & .603 & .199 \\
EPROFC & 148 & 12 & 19 & 16.18 & 1.278 & .366 & .199 \\
Valid N (listwise) & 148 & & & & & \\
\hline
\end{tabular}

\begin{tabular}{|l|r|r|}
\hline \multicolumn{2}{|c|}{ Descriptive Statistics } \\
\cline { 2 - 3 } & \multicolumn{2}{|c|}{ Kurtosis } \\
\hline ACCTP & Statistic & Std. Error \\
EINTG & & -.894 \\
EOBJ & .217 & .396 \\
EPROFB & -.544 & .396 \\
EPROFC & -.515 & .396 \\
Valid N (listwise) & -.203 & .396 \\
\end{tabular}

FREQUENCIES VARIABLES=SEX AGE EDUQ PROFQ WKEXP DESIG /STATISTICS=MEAN MEDIAN MODE SKEWNESS SESKEW KURTOSIS SEKURT /ORDER=ANALYSIS.

\section{Frequencies}

Statistics

\begin{tabular}{|c|c|c|c|c|c|c|}
\hline & SEX & AGE & EDUQ & PROFQ & WKEXP & DESIG \\
\hline Valid & 148 & 148 & 148 & 148 & 148 & 148 \\
\hline Missing & 0 & 0 & 0 & 0 & 0 & 0 \\
\hline Mean & 1.51 & 2.14 & 3.10 & 1.01 & 1.98 & 2.17 \\
\hline Median & 2.00 & 2.00 & 3.00 & 1.00 & 2.00 & 2.00 \\
\hline Mode & 2 & 2 & 3 & 1 & 2 & 1 \\
\hline Skewness & -.055 & .333 & -.546 & 12.166 & .638 & .476 \\
\hline Std. Error of Skewness & .199 & .199 & .199 & .199 & .199 & .199 \\
\hline Kurtosis & -2.025 & -.536 & .972 & 148.000 & -.282 & -1.472 \\
\hline Std. Error of Kurtosis & .396 & .396 & .396 & .396 & .396 & .396 \\
\hline
\end{tabular}

Frequency Table

SEX

\begin{tabular}{|c|c|c|c|c|c|}
\hline & & Frequency & Percent & Valid Percent & $\begin{array}{l}\text { Cumulative } \\
\text { Percent }\end{array}$ \\
\hline \multirow{3}{*}{ Valid } & 1 & 72 & 48.6 & 48.6 & 48.6 \\
\hline & 2 & 76 & 51.4 & 51.4 & 100.0 \\
\hline & Total & 148 & 100.0 & 100.0 & \\
\hline
\end{tabular}

\begin{tabular}{|c|c|c|c|c|c|}
\hline & & Frequency & Percent & Valid Percent & $\begin{array}{c}\text { Cumulative } \\
\text { Percent }\end{array}$ \\
\hline \multirow{5}{*}{ Valid } & 1 & 36 & 24.3 & 24.3 & 24.3 \\
\hline & 2 & 65 & 43.9 & 43.9 & 68.2 \\
\hline & 3 & 38 & 25.7 & 25.7 & 93.9 \\
\hline & 4 & 9 & 6.1 & 6.1 & 100.0 \\
\hline & Total & 148 & 100.0 & 100.0 & \\
\hline
\end{tabular}


EDUQ

\begin{tabular}{|c|c|c|c|c|c|}
\hline & & Frequency & Percent & Valid Percent & $\begin{array}{c}\text { Cumulative } \\
\text { Percent }\end{array}$ \\
\hline \multirow{5}{*}{ Valid } & 1 & 3 & 2.0 & 2.0 & 2.0 \\
\hline & 2 & 16 & 10.8 & 10.8 & 12.8 \\
\hline & 3 & 92 & 62.2 & 62.2 & 75.0 \\
\hline & 4 & 37 & 25.0 & 25.0 & 100.0 \\
\hline & Total & 148 & 100.0 & 100.0 & \\
\hline
\end{tabular}

PROFQ

\begin{tabular}{|rl|r|r|r|r|}
\hline & Frequency & Percent & Valid Percent & $\begin{array}{c}\text { Cumulative } \\
\text { Percent }\end{array}$ \\
\hline \multirow{3}{*}{ Valid } & 1 & 147 & 99.3 & 99.3 & 99.3 \\
& 3 & 1 & .7 & .7 & 100.0 \\
& Total & 148 & 100.0 & 100.0 & \\
\hline
\end{tabular}

WKEXP

\begin{tabular}{|c|c|c|c|c|c|}
\hline & & Frequency & Percent & Valid Percent & $\begin{array}{c}\text { Cumulative } \\
\text { Percent }\end{array}$ \\
\hline \multirow{5}{*}{ Valid } & 1 & 49 & 33.1 & 33.1 & 33.1 \\
\hline & 2 & 63 & 42.6 & 42.6 & 75.7 \\
\hline & 3 & 26 & 17.6 & 17.6 & 93.2 \\
\hline & 4 & 10 & 6.8 & 6.8 & 100.0 \\
\hline & Total & 148 & 100.0 & 100.0 & \\
\hline
\end{tabular}

DESING

\begin{tabular}{|c|c|c|c|c|c|}
\hline & & Frequency & Percent & Valid Percent & $\begin{array}{c}\text { Cumulative } \\
\text { Percent }\end{array}$ \\
\hline \multirow{5}{*}{ Valid } & 1 & 68 & 45.9 & 45.9 & 45.9 \\
\hline & 2 & 26 & 17.6 & 17.6 & 63.5 \\
\hline & 3 & 15 & 10.1 & 10.1 & 73.6 \\
\hline & 4 & 39 & 26.4 & 26.4 & 100.0 \\
\hline & Total & 148 & 100.0 & 100.0 & \\
\hline
\end{tabular}




IISE

Regression
\begin{tabular}{|l|r|r|r|}
\hline & \multicolumn{3}{c|}{ Descriptive Statistics } \\
\hline ACCTP & Mean & Std. Deviation & \multicolumn{1}{c|}{ N } \\
EINTG & 5.7635 & 1.25281 & 148 \\
EOBJ & 16.42 & 1.050 & 148 \\
EPROFB & 16.30 & 1.193 & 148 \\
EPROFC & 16.01 & .979 & 148 \\
\hline
\end{tabular}

Correlations

\begin{tabular}{|ll|r|r|r|r|r|}
\hline & & ACCTP & EINTG & EOBJ & EPROFB & EPROFC \\
\hline & ACCTP & 1.000 & -.457 & -.775 & -.254 & -.610 \\
& EINTG & -.457 & 1.000 & .413 & .024 & .247 \\
Pearson Correlation & EOBJ & -.775 & .413 & 1.000 & .155 & .619 \\
& EPROFB & -.254 & .024 & .155 & 1.000 & .113 \\
& EPROFC & -.610 & .247 & .619 & .113 & 1.000 \\
& ACCTP & .000 & .000 & .001 & .000 \\
Sig. (1-tailed) & EINTG & .000 & .000 & .388 & .001 \\
& EOBJ & .000 & .000 & .000 & .030 & .000 \\
& EPROFB & .001 & .388 & .030 & .085 \\
& EPROFC & .000 & .001 & .000 & .085 & .085 \\
& ACCTP & 148 & 148 & 148 & 148 & 148 \\
$\mathrm{~N}$ & EINTG & 148 & 148 & 148 & 148 & 148 \\
& EOBJ & 148 & 148 & 148 & 148 & 148 \\
& EPROFB & 148 & 148 & 148 & 148 & 148 \\
& EPROFC & 148 & 148 & 148 & 148 & 148 \\
\hline
\end{tabular}

Variables Entered/Removed ${ }^{\mathrm{a}}$

\begin{tabular}{|l|l|l|l|}
\hline \multirow{2}{*}{ Model } & \multicolumn{1}{|c|}{$\begin{array}{l}\text { Variables } \\
\text { Entered }\end{array}$} & $\begin{array}{c}\text { Variables } \\
\text { Removed }\end{array}$ & Method \\
\hline \multirow{2}{*}{1} & $\begin{array}{l}\text { EPROFC, } \\
\text { EPROFB, } \\
\text { EINTG, EOBJ }\end{array}$ & & Enter \\
\hline
\end{tabular}

a. Dependent Variable: ACCTP

b. All requested variables entered.

Model Summary ${ }^{b}$

\begin{tabular}{|c|c|c|c|c|c|c|c|}
\hline \multirow[t]{2}{*}{ Model } & \multirow[t]{2}{*}{$\mathrm{R}$} & \multirow[t]{2}{*}{ R Square } & \multirow{2}{*}{$\begin{array}{c}\text { Adjusted R } \\
\text { Square }\end{array}$} & \multirow{2}{*}{$\begin{array}{l}\text { Std. Error of the } \\
\text { Estimate }\end{array}$} & \multicolumn{3}{|c|}{ Change Statistics } \\
\hline & & & & & $\begin{array}{c}\text { R Square } \\
\text { Change }\end{array}$ & F Change & df1 \\
\hline 1 & $.819^{\mathrm{a}}$ & .671 & .661 & .72898 & .671 & 72.793 & 4 \\
\hline
\end{tabular}

Model Summary ${ }^{b}$

\begin{tabular}{|l|rr|r|r|}
\hline \multirow{2}{*}{ Model } & \multicolumn{3}{|c|}{ Change Statistics } & \multicolumn{2}{|c|}{ Durbin-Watson } \\
\cline { 2 - 3 } & df2 & Sig. F Change & 1.959 \\
\hline 1
\end{tabular}

a. Predictors: (Constant), EPROFC, EPROFB, EINTG, EOBJ

b. Dependent Variable: ACCTP 
ANOVA $^{\mathrm{a}}$

\begin{tabular}{|rl|r|r|r|r|r|}
\hline Model & & Sum of Squares & Df & Mean Square & F & Sig. \\
\hline \multirow{2}{*}{1} & Regression & 154.731 & 4 & 38.683 & 72.793 & $.000^{\mathrm{b}}$ \\
& Residual & 75.992 & 143 & .531 & & \\
& Total & 230.723 & 147 & & & \\
\hline
\end{tabular}

a. Dependent Variable: ACCTP

b. Predictors: (Constant), EPROFC, EPROFB, EINTG, EOBJ

Coefficients $^{\mathbf{a}}$

\begin{tabular}{|c|c|c|c|c|c|c|c|}
\hline \multirow{2}{*}{\multicolumn{2}{|c|}{ Model }} & \multicolumn{2}{|c|}{ Unstandardized Coefficients } & \multirow{2}{*}{$\begin{array}{c}\text { Standardized } \\
\text { Coefficients } \\
\text { Beta }\end{array}$} & \multirow[t]{2}{*}{$\mathrm{t}$} & \multirow[t]{2}{*}{ Sig. } & \multirow{2}{*}{$\begin{array}{c}\text { Collinearity } \\
\text { Statistics } \\
\text { Tolerance }\end{array}$} \\
\hline & & B & Std. Error & & & & \\
\hline \multirow{5}{*}{1} & (Constant) & 24.808 & 1.419 & & 17.482 & .000 & \\
\hline & EINTG & -.207 & .063 & -.174 & -3.291 & .001 & .827 \\
\hline & EOBJ & -.579 & .069 & -.552 & -8.421 & .000 & .537 \\
\hline & EPROFB & -.179 & .062 & -.140 & -2.881 & .005 & .973 \\
\hline & EPROFC & -.206 & .060 & -.210 & -3.434 & .001 & .616 \\
\hline
\end{tabular}

Coefficients $^{\mathrm{a}}$

\begin{tabular}{|c|c|c|}
\hline Model & & Collinearity Statistics \\
\hline & (Constant) & \\
\hline & EINTG & 1.209 \\
\hline 1 & EOBJ & 1.863 \\
\hline & EPROFB & 1.027 \\
\hline & EPROFC & 1.623 \\
\hline
\end{tabular}

a. Dependent Variable: ACCTP

a. Dependent Variable: ACCTP

Residuals Statistics ${ }^{a}$

\begin{tabular}{|l|r|r|r|r|r|}
\hline & Minimum & Maximum & Mean & \multicolumn{1}{c|}{$\begin{array}{c}\text { Std. } \\
\text { Deviation }\end{array}$} & $\mathrm{N}$ \\
\hline Predicted Value & 2.3023 & 7.2366 & 5.7635 & 1.02596 & 148 \\
Residual & -1.85015 & 2.53135 & .00000 & .71899 & 148 \\
Std. Predicted & -3.374 & 1.436 & .000 & 1.000 & 148 \\
Value & -2.538 & 3.472 & .000 & .986 & 148 \\
Std. Residual &
\end{tabular}

a. Dependent Variable: ACCTP

b. 


\begin{tabular}{|c|c|c|c|c|c|c|c|c|c|c|c|c|c|c|c|c|}
\hline$\frac{\Omega}{Z}$ & $\begin{array}{l}\mathscr{a} \\
\underset{11}{x} \\
x\end{array}$ & 党 & 雨 & $\begin{array}{l}\overrightarrow{7} \\
0 \\
0 \\
0 \\
0\end{array}$ & 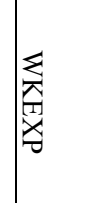 & 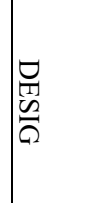 & $\stackrel{\vec{\Omega}}{\widehat{\Omega}}$ & $\stackrel{\mathbb{Z}}{\underset{Z}{Z}}$ & 苗 & 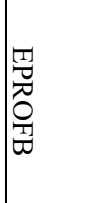 & 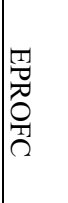 & 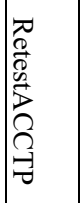 & 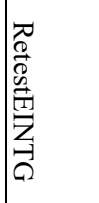 & 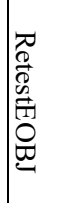 & 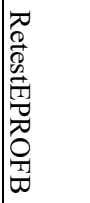 & 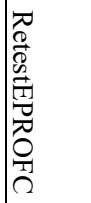 \\
\hline 1 & 1 & 3 & 4 & 1 & 4 & 4 & 7 & 15 & 15 & 15 & 15 & 7 & 14 & 15 & 15 & 15 \\
\hline 2 & 1 & 2 & 3 & 1 & 2 & 1 & 7 & 15 & 15 & 15 & 15 & 7 & 15 & 15 & 15 & 15 \\
\hline 3 & 1 & 1 & 3 & 1 & 1 & 1 & 7 & 15 & 15 & 15 & 15 & 7 & 14 & 15 & 15 & 15 \\
\hline 4 & 2 & 1 & 3 & 1 & 1 & 4 & 7 & 15 & 15 & 15 & 15 & 7 & 15 & 15 & 15 & 15 \\
\hline 5 & 2 & 3 & 3 & 1 & 1 & 4 & 7 & 15 & 15 & 15 & 15 & 7 & 13 & 15 & 15 & 15 \\
\hline 6 & 2 & 2 & 3 & 1 & 3 & 1 & 7 & 15 & 15 & 15 & 17 & 7 & 15 & 15 & 15 & 17 \\
\hline 7 & 1 & 1 & 3 & 1 & 1 & 2 & 7 & 15 & 15 & 15 & 18 & 7 & 13 & 15 & 15 & 18 \\
\hline 8 & 2 & 2 & 3 & 1 & 2 & 1 & 7 & 15 & 15 & 16 & 15 & 7 & 15 & 15 & 16 & 15 \\
\hline 9 & 2 & 1 & 3 & 1 & 1 & 4 & 7 & 15 & 15 & 16 & 15 & 7 & 15 & 15 & 16 & 15 \\
\hline 10 & 1 & 2 & 3 & 1 & 2 & 4 & 7 & 15 & 15 & 16 & 15 & 7 & 16 & 15 & 16 & 15 \\
\hline 11 & 1 & 4 & 4 & 1 & 4 & 4 & 7 & 15 & 15 & 16 & 15 & 7 & 15 & 15 & 16 & 15 \\
\hline 12 & 2 & 2 & 3 & 1 & 3 & 3 & 7 & 15 & 15 & 16 & 18 & 7 & 15 & 15 & 16 & 18 \\
\hline 13 & 1 & 3 & 4 & 1 & 4 & 4 & 7 & 15 & 15 & 17 & 15 & 7 & 15 & 15 & 17 & 15 \\
\hline 14 & 1 & 3 & 3 & 1 & 2 & 1 & 6 & 15 & 15 & 17 & 15 & 6 & 16 & 15 & 17 & 15 \\
\hline 15 & 2 & 2 & 3 & 1 & 3 & 4 & 7 & 15 & 15 & 17 & 16 & 7 & 15 & 15 & 17 & 16 \\
\hline 16 & 2 & 1 & 3 & 1 & 1 & 4 & 7 & 15 & 15 & 18 & 15 & 7 & 15 & 15 & 18 & 15 \\
\hline 17 & 1 & 1 & 3 & 1 & 1 & 4 & 6 & 15 & 16 & 15 & 15 & 6 & 15 & 16 & 15 & 15 \\
\hline 18 & 2 & 2 & 4 & 1 & 3 & 3 & 7 & 15 & 16 & 15 & 16 & 7 & 15 & 16 & 15 & 16 \\
\hline 19 & 2 & 3 & 4 & 1 & 3 & 3 & 6 & 15 & 16 & 15 & 16 & 6 & 16 & 16 & 15 & 16 \\
\hline 20 & 2 & 3 & 4 & 1 & 3 & 1 & 6 & 15 & 16 & 16 & 16 & 7 & 15 & 16 & 16 & 16 \\
\hline 21 & 2 & 2 & 3 & 1 & 2 & 1 & 5 & 15 & 16 & 16 & 17 & 7 & 15 & 16 & 16 & 17 \\
\hline 22 & 2 & 2 & 3 & 1 & 2 & 2 & 5 & 15 & 16 & 16 & 17 & 5 & 15 & 16 & 16 & 17 \\
\hline 23 & 1 & 3 & 4 & 1 & 2 & 2 & 7 & 15 & 16 & 17 & 15 & 7 & 15 & 16 & 17 & 15 \\
\hline 24 & 1 & 2 & 4 & 1 & 2 & 1 & 7 & 15 & 16 & 17 & 16 & 7 & 15 & 16 & 17 & 16 \\
\hline 25 & 1 & 2 & 3 & 1 & 2 & 1 & 6 & 15 & 16 & 17 & 16 & 6 & 15 & 16 & 17 & 16 \\
\hline 26 & 1 & 2 & 3 & 1 & 2 & 1 & 7 & 15 & 16 & 19 & 15 & 7 & 15 & 16 & 19 & 16 \\
\hline 27 & 1 & 3 & 4 & 1 & 2 & 1 & 7 & 15 & 17 & 15 & 15 & 7 & 15 & 17 & 15 & 15 \\
\hline 28 & 1 & 3 & 4 & 1 & 4 & 3 & 5 & 15 & 17 & 15 & 16 & 7 & 15 & 17 & 15 & 16 \\
\hline 29 & 2 & 2 & 2 & 1 & 2 & 4 & 5 & 15 & 17 & 17 & 16 & 7 & 15 & 17 & 17 & 16 \\
\hline 30 & 2 & 1 & 3 & 1 & 2 & 1 & 5 & 15 & 17 & 18 & 17 & 7 & 15 & 17 & 18 & 17 \\
\hline 31 & 2 & 3 & 4 & 1 & 3 & 3 & 6 & 15 & 18 & 17 & 16 & 6 & 15 & 18 & 17 & 16 \\
\hline 32 & 1 & 1 & 3 & 1 & 1 & 1 & 7 & 16 & 15 & 15 & 15 & 7 & 16 & 15 & 15 & 15 \\
\hline 33 & 2 & 1 & 3 & 1 & 1 & 4 & 7 & 16 & 15 & 15 & 15 & 7 & 16 & 15 & 15 & 15 \\
\hline 34 & 1 & 2 & 3 & 1 & 2 & 4 & 7 & 16 & 15 & 15 & 15 & 7 & 16 & 15 & 15 & 17 \\
\hline 35 & 1 & 1 & 1 & 1 & 1 & 1 & 7 & 16 & 15 & 15 & 15 & 6 & 16 & 15 & 15 & 15 \\
\hline 36 & 1 & 3 & 3 & 1 & 2 & 1 & 7 & 16 & 15 & 15 & 15 & 7 & 16 & 15 & 15 & 15 \\
\hline 37 & 1 & 2 & 3 & 1 & 2 & 1 & 7 & 16 & 15 & 15 & 15 & 7 & 16 & 15 & 15 & 15 \\
\hline 38 & 2 & 2 & 2 & 1 & 1 & 1 & 7 & 16 & 15 & 15 & 15 & 7 & 16 & 15 & 15 & 17 \\
\hline 39 & 2 & 2 & 3 & 1 & 1 & 3 & 7 & 16 & 15 & 15 & 15 & 7 & 16 & 15 & 15 & 15 \\
\hline
\end{tabular}




\begin{tabular}{|c|c|c|c|c|c|c|c|c|c|c|c|c|c|c|c|c|}
\hline 40 & 2 & 3 & 4 & 1 & 3 & 1 & 7 & 16 & 15 & 15 & 17 & 6 & 16 & 15 & 15 & 17 \\
\hline 41 & 1 & 2 & 4 & 1 & 3 & 1 & 5 & 16 & 15 & 15 & 17 & 6 & 16 & 15 & 15 & 17 \\
\hline 42 & 1 & 1 & 3 & 1 & 2 & 1 & 7 & 16 & 15 & 15 & 19 & 7 & 16 & 15 & 15 & 19 \\
\hline 43 & 1 & 2 & 3 & 1 & 2 & 2 & 7 & 16 & 15 & 16 & 15 & 7 & 16 & 15 & 16 & 15 \\
\hline 44 & 2 & 4 & 3 & 1 & 4 & 4 & 7 & 16 & 15 & 16 & 15 & 7 & 16 & 15 & 16 & 15 \\
\hline 45 & 1 & 1 & 3 & 1 & 1 & 1 & 7 & 16 & 15 & 16 & 15 & 7 & 15 & 15 & 16 & 15 \\
\hline 46 & 2 & 2 & 3 & 1 & 3 & 1 & 7 & 16 & 15 & 16 & 15 & 7 & 15 & 15 & 16 & 15 \\
\hline 47 & 1 & 3 & 3 & 1 & 3 & 2 & 7 & 16 & 15 & 16 & 15 & 6 & 15 & 15 & 16 & 15 \\
\hline 48 & 1 & 1 & 3 & 1 & 1 & 2 & 5 & 16 & 15 & 16 & 15 & 7 & 15 & 15 & 16 & 15 \\
\hline 49 & 2 & 1 & 3 & 1 & 1 & 1 & 7 & 16 & 15 & 17 & 15 & 7 & 15 & 15 & 17 & 15 \\
\hline 50 & 1 & 3 & 4 & 1 & 3 & 1 & 6 & 16 & 15 & 17 & 15 & 6 & 15 & 15 & 17 & 15 \\
\hline 51 & 2 & 3 & 4 & 1 & 2 & 1 & 7 & 16 & 15 & 17 & 15 & 7 & 15 & 15 & 17 & 15 \\
\hline 52 & 1 & 3 & 3 & 1 & 3 & 1 & 7 & 16 & 15 & 17 & 15 & 7 & 15 & 15 & 17 & 15 \\
\hline 53 & 2 & 2 & 3 & 1 & 1 & 4 & 7 & 16 & 15 & 17 & 16 & 7 & 15 & 15 & 17 & 16 \\
\hline 54 & 2 & 2 & 3 & 1 & 2 & 1 & 6 & 16 & 16 & 15 & 15 & 6 & 15 & 16 & 15 & 15 \\
\hline 55 & 1 & 2 & 3 & 1 & 2 & 2 & 6 & 16 & 16 & 15 & 17 & 7 & 16 & 16 & 15 & 17 \\
\hline 56 & 1 & 3 & 3 & 1 & 2 & 4 & 7 & 16 & 16 & 16 & 16 & 7 & 16 & 16 & 16 & 16 \\
\hline 57 & 2 & 1 & 3 & 1 & 1 & 2 & 5 & 16 & 17 & 15 & 16 & 5 & 16 & 17 & 15 & 16 \\
\hline 58 & 1 & 1 & 3 & 1 & 2 & 2 & 5 & 16 & 17 & 15 & 17 & 7 & 16 & 17 & 15 & 17 \\
\hline 59 & 2 & 2 & 2 & 1 & 2 & 4 & 5 & 16 & 17 & 15 & 17 & 5 & 16 & 17 & 15 & 17 \\
\hline 60 & 1 & 2 & 3 & 1 & 2 & 1 & 5 & 16 & 17 & 15 & 17 & 5 & 16 & 17 & 15 & 17 \\
\hline 61 & 2 & 3 & 2 & 1 & 2 & 4 & 4 & 16 & 17 & 15 & 18 & 7 & 16 & 17 & 15 & 18 \\
\hline 62 & 2 & 2 & 4 & 1 & 2 & 2 & 5 & 16 & 17 & 16 & 18 & 5 & 16 & 17 & 16 & 18 \\
\hline 63 & 2 & 2 & 3 & 1 & 2 & 1 & 5 & 16 & 17 & 17 & 15 & 5 & 16 & 17 & 17 & 15 \\
\hline 64 & 2 & 4 & 4 & 1 & 4 & 2 & 5 & 16 & 17 & 17 & 15 & 7 & 16 & 17 & 17 & 15 \\
\hline 65 & 2 & 2 & 3 & 1 & 2 & 1 & 5 & 16 & 17 & 17 & 16 & 5 & 16 & 17 & 17 & 16 \\
\hline 66 & 1 & 1 & 3 & 1 & 1 & 4 & 6 & 16 & 17 & 17 & 17 & 6 & 16 & 17 & 17 & 17 \\
\hline 67 & 2 & 2 & 2 & 1 & 2 & 1 & 4 & 16 & 17 & 17 & 17 & 7 & 16 & 17 & 17 & 17 \\
\hline 68 & 1 & 3 & 3 & 1 & 2 & 1 & 7 & 16 & 17 & 17 & 18 & 7 & 16 & 17 & 17 & 18 \\
\hline 69 & 2 & 2 & 3 & 1 & 3 & 4 & 5 & 16 & 17 & 17 & 18 & 5 & 16 & 17 & 17 & 18 \\
\hline 70 & 2 & 2 & 3 & 1 & 2 & 2 & 4 & 16 & 17 & 17 & 18 & 7 & 16 & 17 & 17 & 18 \\
\hline 71 & 1 & 2 & 3 & 1 & 1 & 1 & 4 & 16 & 17 & 18 & 17 & 7 & 16 & 17 & 18 & 17 \\
\hline 72 & 2 & 3 & 3 & 1 & 2 & 4 & 4 & 16 & 17 & 18 & 18 & 7 & 16 & 17 & 18 & 18 \\
\hline 73 & 2 & 2 & 3 & 1 & 1 & 3 & 5 & 16 & 17 & 18 & 19 & 5 & 16 & 17 & 18 & 19 \\
\hline 74 & 1 & 2 & 4 & 1 & 2 & 4 & 7 & 16 & 18 & 15 & 18 & 7 & 16 & 18 & 15 & 18 \\
\hline 75 & 2 & 4 & 4 & 1 & 4 & 3 & 7 & 16 & 18 & 15 & 19 & 7 & 16 & 18 & 15 & 19 \\
\hline 76 & 1 & 2 & 2 & 1 & 1 & 4 & 4 & 16 & 18 & 16 & 15 & 4 & 16 & 18 & 16 & 15 \\
\hline 77 & 2 & 2 & 2 & 1 & 2 & 2 & 4 & 16 & 18 & 16 & 17 & 7 & 16 & 18 & 16 & 17 \\
\hline 78 & 2 & 1 & 3 & 1 & 1 & 4 & 5 & 16 & 18 & 17 & 17 & 7 & 16 & 18 & 17 & 17 \\
\hline 79 & 1 & 3 & 3 & 1 & 3 & 2 & 5 & 16 & 18 & 18 & 18 & 5 & 16 & 18 & 18 & 18 \\
\hline 80 & 1 & 2 & 2 & 1 & 2 & 4 & 4 & 16 & 19 & 15 & 19 & 7 & 16 & 19 & 15 & 19 \\
\hline 81 & 2 & 2 & 3 & 1 & 2 & 4 & 7 & 17 & 15 & 15 & 15 & 7 & 17 & 15 & 15 & 15 \\
\hline 82 & 2 & 3 & 4 & 1 & 3 & 4 & 7 & 17 & 15 & 15 & 15 & 7 & 17 & 15 & 15 & 15 \\
\hline 83 & 1 & 4 & 4 & 1 & 2 & 2 & 7 & 17 & 15 & 15 & 15 & 7 & 17 & 15 & 15 & 15 \\
\hline
\end{tabular}




\begin{tabular}{|c|c|c|c|c|c|c|c|c|c|c|c|c|c|c|c|c|}
\hline 84 & 2 & 1 & 3 & 1 & 1 & 2 & 7 & 17 & 15 & 15 & 16 & 7 & 17 & 15 & 15 & 16 \\
\hline 85 & 1 & 1 & 1 & 3 & 1 & 1 & 5 & 17 & 15 & 15 & 16 & 6 & 18 & 15 & 15 & 16 \\
\hline 86 & 2 & 2 & 3 & 1 & 2 & 2 & 7 & 17 & 15 & 15 & 16 & 7 & 18 & 15 & 15 & 16 \\
\hline 87 & 1 & 2 & 1 & 1 & 3 & 1 & 7 & 17 & 15 & 15 & 16 & 7 & 18 & 15 & 15 & 16 \\
\hline 88 & 2 & 2 & 3 & 1 & 2 & 1 & 7 & 17 & 15 & 16 & 15 & 7 & 18 & 15 & 16 & 15 \\
\hline 89 & 1 & 3 & 4 & 1 & 2 & 1 & 7 & 17 & 15 & 16 & 15 & 7 & 18 & 15 & 16 & 15 \\
\hline 90 & 1 & 3 & 2 & 1 & 2 & 1 & 7 & 17 & 15 & 16 & 15 & 7 & 18 & 15 & 16 & 15 \\
\hline 91 & 2 & 3 & 4 & 1 & 3 & 1 & 6 & 17 & 15 & 16 & 16 & 6 & 18 & 15 & 16 & 16 \\
\hline 92 & 1 & 1 & 3 & 1 & 1 & 1 & 7 & 17 & 16 & 15 & 15 & 7 & 18 & 16 & 15 & 15 \\
\hline 93 & 1 & 2 & 3 & 1 & 2 & 4 & 7 & 17 & 16 & 15 & 15 & 7 & 18 & 16 & 15 & 15 \\
\hline 94 & 2 & 2 & 3 & 1 & 2 & 1 & 7 & 17 & 16 & 15 & 15 & 7 & 18 & 16 & 15 & 15 \\
\hline 95 & 2 & 4 & 4 & 1 & 3 & 4 & 7 & 17 & 16 & 15 & 15 & 8 & 18 & 16 & 15 & 15 \\
\hline 96 & 1 & 2 & 3 & 1 & 2 & 1 & 6 & 17 & 16 & 15 & 16 & 6 & 17 & 16 & 15 & 16 \\
\hline 97 & 2 & 1 & 3 & 1 & 1 & 1 & 5 & 17 & 16 & 15 & 16 & 6 & 17 & 16 & 15 & 16 \\
\hline 98 & 1 & 2 & 4 & 1 & 2 & 1 & 6 & 17 & 16 & 16 & 15 & 6 & 17 & 16 & 16 & 15 \\
\hline 99 & 2 & 2 & 2 & 1 & 1 & 3 & 7 & 17 & 16 & 16 & 15 & 7 & 17 & 16 & 16 & 15 \\
\hline 100 & 1 & 2 & 2 & 1 & 2 & 1 & 7 & 17 & 16 & 16 & 15 & 8 & 17 & 16 & 16 & 15 \\
\hline 101 & 1 & 1 & 3 & 1 & 2 & 1 & 6 & 17 & 16 & 16 & 15 & 7 & 17 & 16 & 16 & 15 \\
\hline 102 & 2 & 2 & 3 & 1 & 2 & 1 & 5 & 17 & 16 & 16 & 16 & 5 & 17 & 16 & 16 & 16 \\
\hline 103 & 2 & 1 & 3 & 1 & 2 & 1 & 5 & 17 & 16 & 16 & 16 & 7 & 17 & 16 & 16 & 16 \\
\hline 104 & 2 & 2 & 3 & 1 & 3 & 1 & 5 & 17 & 16 & 16 & 17 & 5 & 17 & 16 & 16 & 17 \\
\hline 105 & 1 & 3 & 2 & 1 & 1 & 2 & 6 & 17 & 16 & 16 & 17 & 7 & 17 & 16 & 16 & 17 \\
\hline 106 & 1 & 4 & 4 & 1 & 4 & 3 & 6 & 17 & 16 & 17 & 15 & 6 & 17 & 16 & 17 & 15 \\
\hline 107 & 1 & 1 & 2 & 1 & 1 & 2 & 6 & 17 & 16 & 17 & 15 & 6 & 17 & 16 & 17 & 15 \\
\hline 108 & 1 & 3 & 3 & 1 & 2 & 1 & 5 & 17 & 16 & 18 & 16 & 6 & 17 & 16 & 18 & 16 \\
\hline 109 & 2 & 1 & 3 & 1 & 1 & 3 & 8 & 17 & 17 & 15 & 15 & 8 & 17 & 17 & 15 & 15 \\
\hline 110 & 2 & 2 & 4 & 1 & 2 & 3 & 5 & 17 & 17 & 15 & 15 & 5 & 17 & 17 & 15 & 15 \\
\hline 111 & 1 & 1 & 4 & 1 & 2 & 2 & 5 & 17 & 17 & 15 & 17 & 5 & 17 & 17 & 15 & 17 \\
\hline 112 & 1 & 1 & 3 & 1 & 1 & 1 & 6 & 17 & 17 & 15 & 17 & 6 & 17 & 17 & 15 & 17 \\
\hline 113 & 2 & 1 & 3 & 1 & 1 & 2 & 5 & 17 & 17 & 16 & 16 & 5 & 17 & 17 & 16 & 16 \\
\hline 114 & 1 & 3 & 4 & 1 & 3 & 1 & 5 & 17 & 17 & 16 & 17 & 6 & 17 & 17 & 16 & 17 \\
\hline 115 & 1 & 3 & 3 & 1 & 2 & 1 & 5 & 17 & 17 & 16 & 17 & 5 & 17 & 17 & 16 & 17 \\
\hline 116 & 1 & 1 & 3 & 1 & 1 & 3 & 4 & 17 & 17 & 16 & 18 & 6 & 17 & 17 & 16 & 18 \\
\hline 117 & 2 & 2 & 3 & 1 & 1 & 1 & 5 & 17 & 17 & 17 & 15 & 5 & 17 & 17 & 17 & 15 \\
\hline 118 & 1 & 4 & 4 & 1 & 2 & 4 & 4 & 17 & 17 & 17 & 15 & 6 & 16 & 17 & 17 & 15 \\
\hline 119 & 2 & 1 & 3 & 1 & 1 & 4 & 5 & 17 & 17 & 17 & 16 & 5 & 17 & 17 & 17 & 16 \\
\hline 120 & 1 & 1 & 2 & 1 & 1 & 4 & 5 & 17 & 17 & 17 & 16 & 6 & 17 & 17 & 17 & 16 \\
\hline 121 & 2 & 2 & 3 & 1 & 3 & 1 & 5 & 17 & 17 & 17 & 17 & 5 & 15 & 17 & 17 & 17 \\
\hline 122 & 1 & 1 & 3 & 1 & 1 & 1 & 5 & 17 & 18 & 15 & 16 & 6 & 17 & 18 & 15 & 16 \\
\hline 123 & 2 & 3 & 4 & 1 & 4 & 1 & 5 & 17 & 18 & 15 & 17 & 5 & 16 & 18 & 15 & 17 \\
\hline 124 & 2 & 2 & 3 & 1 & 1 & 1 & 4 & 17 & 18 & 16 & 16 & 6 & 17 & 18 & 16 & 16 \\
\hline 125 & 1 & 2 & 3 & 1 & 2 & 1 & 5 & 17 & 18 & 16 & 17 & 5 & 16 & 18 & 16 & 17 \\
\hline 126 & 1 & 2 & 3 & 1 & 1 & 1 & 5 & 17 & 18 & 16 & 17 & 5 & 17 & 18 & 16 & 17 \\
\hline 127 & 2 & 2 & 3 & 1 & 2 & 1 & 4 & 17 & 18 & 16 & 18 & 4 & 18 & 16 & 15 & 18 \\
\hline
\end{tabular}




\begin{tabular}{|l|l|l|l|l|l|l|l|l|l|l|l|l|l|l|l|l|}
\hline 128 & 2 & 3 & 4 & 1 & 3 & 3 & 4 & 17 & 18 & 17 & 17 & 4 & 17 & 18 & 17 & 17 \\
\hline 129 & 2 & 4 & 4 & 1 & 4 & 4 & 4 & 17 & 19 & 15 & 18 & 4 & 17 & 19 & 15 & 18 \\
\hline 130 & 1 & 2 & 3 & 1 & 1 & 1 & 8 & 18 & 15 & 15 & 12 & 8 & 16 & 14 & 15 & 12 \\
\hline 131 & 2 & 3 & 3 & 1 & 3 & 4 & 7 & 18 & 15 & 18 & 17 & 7 & 16 & 15 & 16 & 17 \\
\hline 132 & 2 & 2 & 2 & 1 & 1 & 4 & 5 & 18 & 16 & 15 & 17 & 5 & 16 & 16 & 15 & 17 \\
\hline 133 & 2 & 3 & 4 & 1 & 1 & 4 & 7 & 18 & 16 & 17 & 15 & 7 & 16 & 16 & 17 & 15 \\
\hline 134 & 1 & 3 & 4 & 1 & 3 & 3 & 5 & 18 & 17 & 16 & 15 & 5 & 16 & 17 & 16 & 15 \\
\hline 135 & 2 & 1 & 3 & 1 & 1 & 4 & 4 & 18 & 17 & 17 & 17 & 4 & 16 & 14 & 17 & 17 \\
\hline 136 & 2 & 2 & 4 & 1 & 2 & 2 & 4 & 18 & 17 & 18 & 17 & 4 & 16 & 17 & 17 & 17 \\
\hline 137 & 2 & 1 & 3 & 1 & 1 & 1 & 4 & 18 & 17 & 18 & 17 & 4 & 15 & 17 & 18 & 17 \\
\hline 138 & 2 & 2 & 3 & 1 & 1 & 4 & 5 & 18 & 18 & 15 & 17 & 5 & 16 & 18 & 17 & 17 \\
\hline 139 & 2 & 3 & 2 & 1 & 3 & 2 & 4 & 18 & 18 & 15 & 18 & 4 & 16 & 18 & 15 & 18 \\
\hline 140 & 2 & 2 & 3 & 1 & 2 & 2 & 4 & 18 & 18 & 16 & 18 & 7 & 16 & 15 & 17 & 18 \\
\hline 141 & 1 & 2 & 3 & 1 & 2 & 1 & 3 & 18 & 18 & 16 & 19 & 3 & 18 & 18 & 16 & 19 \\
\hline 142 & 2 & 3 & 4 & 1 & 1 & 2 & 4 & 18 & 19 & 16 & 18 & 4 & 18 & 19 & 16 & 18 \\
\hline 143 & 1 & 3 & 3 & 1 & 2 & 2 & 3 & 18 & 19 & 16 & 18 & 3 & 18 & 19 & 16 & 18 \\
\hline 144 & 2 & 1 & 3 & 1 & 1 & 1 & 4 & 19 & 17 & 16 & 17 & 6 & 19 & 17 & 16 & 17 \\
\hline 145 & 1 & 3 & 3 & 1 & 2 & 1 & 4 & 19 & 17 & 17 & 18 & 7 & 19 & 17 & 17 & 18 \\
\hline 146 & 1 & 2 & 3 & 1 & 1 & 1 & 4 & 19 & 18 & 17 & 17 & 4 & 19 & 18 & 17 & 17 \\
\hline 147 & 1 & 2 & 3 & 1 & 1 & 4 & 4 & 19 & 18 & 17 & 19 & 4 & 19 & 18 & 17 & 19 \\
\hline 148 & 1 & 2 & 3 & 1 & 2 & 1 & 2 & 20 & 20 & 16 & 19 & 2 & 20 & 20 & 16 & 19 \\
\hline
\end{tabular}

